\title{
A Feasibility Study of \\ Sustainable Distributed Generation Technologies \\ to Improve the Electric System \\ on the Duck Valley Reservation
}

FINAL REPORT

June 2005

Submitted to the US Department of Energy in Response to:

DE-PS36-02G092006

Renewable Energy Development on Tribal Lands

Submitted by:

Shoshone-Paiute Tribes of the

Duck Valley Reservation

Business Contact:

Herman Atkins, Tribal Programs Administrator

Duck Valley Reservation

PO Box 219

Owyhee, NV 89832

775 757-3161

dvir4@aol.com

Technical Contact:

Mark Hannifan

New West Technologies, LLC

383 Inverness Parkway, Suite 330

Englewood, CO 80112

$303792-3736$

303 792-3759 (fax)

hannifan@newwesttech.us 


\section{TABLE OF CONTENTS}

1.0 BACKGROUND

2.0 ASSESSMENT OF THE ELECTRIC DISTRIBUTION SYSTEM (PART 1)

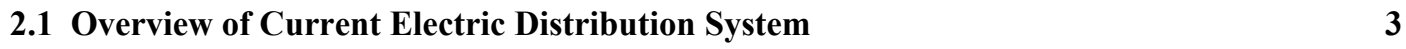

$\begin{array}{ll}\text { 2.2 Part } 1 \text { Assessment Tasks } & 3\end{array}$

2.3 Identification and Characterization of System Reliability and Deliverability Problems 4

2.4 Strategies for Improving Electric Distribution System Reliability 4

2.5 Assessment of Energy Efficiency Opportunities 4

3.0 ASSESSMENT OF SUSTAINABLE DG TECHNOLOGIES (PART 2)

$\begin{array}{llr}\text { 3.1 Part } 2 \text { Assessment Tasks } & 5\end{array}$

$\begin{array}{lr}\text { 3.2 Wind Power } & 5\end{array}$

3.2.1 Overview of Previous Wind Resource Characterizations at Duck Valley $\quad 5$

3.2.2 Overview of Current Wind Resource Characterizations at Duck Valley $\quad 8$

3.2.3 Results of Wind Resource Data Collection at Duck Valley 9

3.2.4 Next Steps for Duck Valley Wind Development Efforts 11

$\begin{array}{lr}\text { 3.3 Solar Power } & 12\end{array}$

$\begin{array}{lr}3.4 \text { Fuel Cells } & 13\end{array}$

4.0 SUMMARY OF BENEFITS/BARRIERS AND IMPLEMENTATION REQUIREMENTS 14

$\begin{array}{ll}\text { 4.1 Benefits and Barriers } & 14\end{array}$

$\begin{array}{ll}\text { 4.2 Required Steps for Project Implementation } & 14\end{array}$

APPENDIX A LIGHTING INVENTORY DATA FOR DUCK VALLEY BUILDINGS 17

APPENDIX B WIND ANALYSIS SUMMARY REPORTS (MILLER CREEK SITE) 37 


\subsection{BACKGROUND}

The 453 square mile Duck Valley Indian Reservation, home to bands of the Shoshone and Paiute Tribes, straddles the Nevada-Idaho borders and is situated in one of the most remote and thinly populated areas of the lower 48 states. The Reservation is home to about 1,100 people, with an unemployment rate of about $40 \%$.

Land within the Reservation is fairly diverse, ranging from the Owyhee River Valley up into high desert country and mountains. Because of its high desert climate, the Reservation is blessed with high annual average solar radiation $(90 \%+$ days with sunshine in summer, $\sim 70 \%$ days with sunshine in winter) and several areas of the Reservation experience high annual average wind speeds.

The electric distribution system that feeds the Reservation has been chronically susceptible to outages, and multi-day system outages are not uncommon due to the remoteness of the lines. The main feeder line serving the Reservation is also rapidly approaching its capacity limit. Both of these factors have negatively affected the Tribes' plans to promote economic development on the Reservation.

In response to these power issues, the Tribes' recently developed Economic Development Strategic Plan identified the need for an assessment of the potential for alternative energy technologies to improve the reliability and deliverability of electric power on the Reservation. With funding support from the US Department of Energy's (DOE) Tribal Energy Program, the Project Team conducted A Feasibility Study of Sustainable Distributed Generation Technologies to Improve the Electric System on the Duck Valley Reservation in two parts:

- An assessment of the electric distribution system serving the Reservation, including a review of on- and off-Reservation power lines and substations, an inventory and characterization of on-Reservation electrical loads, and an assessment of electrical energy efficiency improvement opportunities;

An assessment of the technical and economic feasibility of renewable-based distributed generation technologies including wind turbines, solar photovoltaics, and stationary fuel cells.

The assessment was conducted as a partnership of the Duck Valley Tribes, New West Technologies of Englewood, Colorado CSHQA of Boise, Idaho, Idaho National Environmental Engineering Laboratory, and the Idaho Department of Water Resources. 


\subsection{ASSESSMENT OF THE ELECTRIC DISTRIBUTION SYSTEM (PART 1)}

\subsection{Overview of Current Electric Distribution System}

In response to high unemployment and the desire to expand economic development on the Reservation, the Duck Valley Tribes are pursuing initiatives in the areas of agriculture/ranching, outdoor recreation and tourism, and downtown revitalization. An impediment to these economic development initiatives, however, is the Reservation's electric distribution system.

Duck Valley Reservation is at the "end of the line" in terms of electric service. The Reservation is served by a single $34.5 \mathrm{kV}$ distribution line that originates at a substation in Mountain City, Nevada (12 miles off the Reservation to the southeast) and dead ends on the Reservation. ${ }^{1}$ No other electric interconnect option is

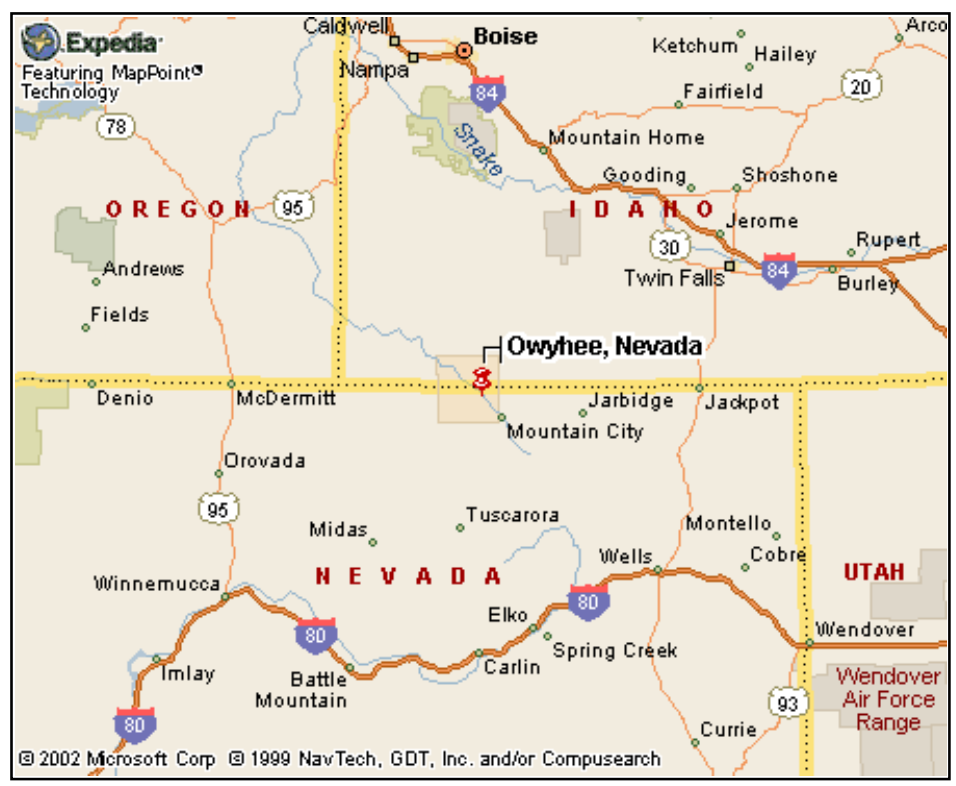
available within 60 miles. The $69 \mathrm{kV}$ transmission line upstream of Mountain City (some sections of which were constructed in the 1930s) is chronically susceptible to outages, with the Reservation experiencing as many as 12 outages per year lasting over 8 hours per outage.

The distribution system serving the Reservation is also rapidly approaching its capacity limit. The 69/34.5 transformer at Mountain City substation is rated at 6.25 MVa, and system loads on the Reservation have recently approached $6.0 \mathrm{MVa}$ in the winter. $^{2}$ These values indicate that there is available capacity for about $0.25 \mathrm{MVa}$ (or $\sim 250 \mathrm{~kW}$ ) of additional load on the distribution side of the substation (i.e. the Reservation). As a result, Raft River Electric Cooperative (RREC) previously advised the Duck Valley Tribes that a proposed retail center (now built) on the Reservation with an estimated peak load of $200 \mathrm{~kW}$ would exceed RREC's ability to provide full electric service to the Reservation. This chronic uncertainty of deliverability of electricity has clouded the Tribes' ability to plan other economic development or infrastructure improvement initiatives.

\subsection{Part 1 Assessment Tasks}

The first part of the Study, as it was originally proposed, involved an assessment of the current electric distribution on the Reservation. In Part 1 the Project Team:

identified the sources of the reliability and deliverability problems;

\footnotetext{
${ }^{1}$ In 2001, Idaho Power sold the distribution system on the Reservation to Raft River Electric Cooperative whom maintains the system.

${ }^{2}$ Duck Valley Reservation electric loads peak in winter due to widespread reliance on electric space heating and electric water heating in buildings.
} 
conducted an assessment of utility bill data and other data available from RREC to determine the magnitude, hours of operation, and coincidence of electric loads on the Reservation (by location and end use) and the intensity of electricity use (e.g. $\mathrm{kW} / \mathrm{ft} 2, \mathrm{kWh} / \mathrm{ft} 2)$;

identified opportunities for deployment of energy efficiency or load reduction measures in buildings and other electric end use applications.

\subsection{Identification and Characterization of System Reliability and Deliverability Problems}

From a review of a RREC "dispatch outage report" associated with the Mountain City substation for the period 1996 to 2002, area-wide power disruptions were primarily caused by four types of events: 5 power disruptions due to "equipment failure", 4 due to "maintenance", 44 due to "loss of supply", and 5 due to "load shedding". The predominant reason by far for power disruptions at the Mountain City substation (and thus on the Duck Valley Reservation) was the loss of upstream electric supply, due mainly to weather-induced failure (e.g. icing, high winds, etc.) of the aging transmission system between the Jarbridge (NV) substation and Mountain City. The "dispatch outage report" also was an early indicator of the carrying capacity constraints that now impact the Reservation as the power disruptions caused by "load shedding" were not evident from 1996 to 2000, but began to occur early in 2001. The possibility of "load shedding" power disruptions continues today, particularly in winter peak electric demand periods.

\subsection{Strategies for Improving Electric Distribution System Reliability}

It was the project team's original intent to pursue discussions with RREC about corrective strategies for improving reliability/deliverability of the existing radial feed system, starting on the Reservation and working upstream. However, soon after startup of the Study, RREC announced that it had received a major grant from the USDA's Rural Utility Service (RUS) to construct a $138 \mathrm{kVa}$ line to the Reservation which would enable the $34.5 \mathrm{kVa}$ distribution system on the Reservation to be interconnected to an entirely new and lightly loaded transmission/distribution system from the north. ${ }^{3}$ Once built in 2007, this new power line will greatly improve both the reliability and deliverability of electric power to the Duck Valley Reservation.

\subsection{Assessment of Energy Efficiency Opportunities}

In an effort to address, in part, the severe constraints for accommodating economic (and thus electric demand) growth on the Reservation, energy audits (with a lighting emphasis) were conducted on the major institutional buildings on the Reservation to determine the potential for reduction of electricity use and electric demand. Room-by-room walkthrough audits of the buildings were conducted in July 2004 to develop inventories and characterizations of existing lighting equipment. Based on the inventories and characterizations, high efficiency replacement equipment was analyzed for electricity and electric demand savings, installation cost, and economic payback.

Appendix A provides a listing of existing lighting equipment and their characteristics for the buildings audited on the Duck Valley Reservation. Appendix A also provides a building-by-building summary of the results of proposed lighting retrofits. In general, a vast majority of the lighting fixtures in the major buildings on the Reservation use previous generation fluorescent lighting technology (i.e. magnetic ballasts and T12 lamps). Further there is a high degree of commonality among the lighting fixtures, meaning that the strategies for retrofitting fixtures can be replicated from building to building.

\footnotetext{
${ }^{3}$ The projected cost of the new line is $\$ 7.5$ million, of which RREC is contributing $\sim \$ 2.3$ million, the Duck Valley Tribes are contributing $\sim \$ 600,000$, and the balance of the funds are from USDA RUS and other project partners.
} 
The preferred retrofit strategy for most of the lighting fixtures is to replace the existing magnetic ballasts with high efficiency electronic ballasts and to replace T12 fluorescent lamps with energy efficient T8 lamps. These changes can be readily implemented by facility maintenance personnel and typically take about 10-15 minutes per fixture to complete.

The following table presents the potential electricity savings, electric demand reduction, installation costs, and payback if a Reservation-wide lighting efficiency program were to be implemented in eight of the larger buildings on the Reservation.

\begin{tabular}{|l|c|c|c|c|}
\hline \multicolumn{5}{|c|}{ Summary Results of Lighting Audits for Major Buildings: Duck Valley Reservation } \\
\hline & $\begin{array}{c}\text { Annual Operating } \\
\text { Cost Savings }\end{array}$ & $\begin{array}{c}\text { Electric Demand } \\
\text { Reduction }\end{array}$ & Cost of Retrofits & Simple Payback \\
\hline $\begin{array}{l}\text { 8 Buildings } \\
\text { (see Appendix A) }\end{array}$ & $\$ 18,500$ & $70+\mathrm{kW}^{*}$ & $\$ 27,000$ & 1.5 Years \\
\hline
\end{tabular}

* If all lighting fixtures are illuminated at same time (say 3:00PM); actual "coincidental" demand reduction is more likely to be 60+ kW.

Even though the cost of electricity on the Reservation is relatively inexpensive $(\$ 0.06 / \mathrm{kWh})$, the payback period for the lighting retrofits is an extremely attractive 1.5 years if the installation labor is provided by existing maintenance personnel. More compelling, however, is an electric load reduction of $60-70 \mathrm{~kW}$ that can be achieved, which frees up that amount of load to accommodate other electric load growth between now and 2007 (when the new transmission line and substation is scheduled to be completed).

Recommendations for implementation of these retrofits are found in Section 4.2.

\subsection{ASSESSMENT OF SUSTAINABLE DG TECHNOLOGIES (PART 2)}

\subsection{Part 2 Assessment Tasks}

While its primary purpose is to provide an alternate source of electric supply to the Duck Valley Reservation, the new $138 \mathrm{kVa}$ transmission line to be built by RREC in partnership with the Duck Valley Tribes (as described in Section 2.4) has emerged as the significant driver in determining which sustainable energy option(s) are most feasible for the Tribes to pursue. Prior to the announcement of the new $138 \mathrm{kVa}$ line, the primary issue was reliability and deliverability (electricity costs are not a high priority, as the area has relatively inexpensive power when the power is flowing), with no prospect for exporting renewable-based electricity off the Reservation. This pre-proposal scenario favored the consideration of small-scale wind, solar photovoltaics, and even propane-fueled fuel cells. With the new transmission line now scheduled for completion by 2007, the emphasis of the Study was redirected at evaluating the feasibility of large-scale wind power for use by the Tribes as well as off-Reservation sales. For educational purposes, information about the applicability of solar photovoltaics and fuels cells on the Reservation is also provided in the following sections.

\subsection{Wind Power}

\subsubsection{Overview of Previous Wind Resource Characterizations at Duck Valley}

The wind resource for the State of Idaho presented on the following pages (with the Duck Valley Reservation indicated in the far southwest part of the State) indicates that lands along the northern and eastern edges of the Reservation have the highest relative wind speeds on the Reservation and compare favorably with other windy area of Idaho. 
To gather site specific on the Duck Valley Reservation, an anemometer was previously installed on the Duck Valley Reservation as part of the NREL Native American Anemometer Loan Program. The initial monitoring site (Site \#3246) was located south of the town of Owyhee at 7180 feet. The monitoring period ran from June 2001 to March 2002, with the annual average wind speed at 20 meters measured to be $16.1 \mathrm{mph}$ (or $~ 18.4 \mathrm{mph}$ at 50 meters). This would be considered a Class 6 (rated "Outstanding") wind resource, albeit based on very short term data. Based on these preliminary results, NREL recommended further study of wind resources on the Reservation, suggesting a full-fledged wind monitoring program.

Although the preliminary data collection effort was encouraging, the initial site chosen on the Reservation was not appropriate for wind farm development. It is remote and difficult to access, would not support more than a few wind turbines, and it is situated 10-15 miles away from the Mountain City substation (across very rugged terrain), which is interconnected to a capacity-constrained and failure-prone transmission line.

Based on the constraints for development of the initial site and the announcement of the new transmission line and substation, the emphasis of wind data collection efforts moved to sites located on the northern half of the Reservation. However, for comparative purposes with other data collection sites on and near the Reservation, the NREL anemometer tower and its instruments were reinstalled and are presently collecting data.

\begin{tabular}{|c|c|}
\hline \multicolumn{2}{|c|}{$\begin{array}{c}\text { Duck Valley Reservation Average Wind Speeds } \\
\text { Site \#3246} \\
(66 \mathrm{ft} .(20 \mathrm{~m}) \text { tower }) \\
\text { N. } 41.8528 \mathrm{deg} ., \text { W. } 116.124 \mathrm{deg} . \\
\text { Elevation }-7180 \mathrm{ft} .\end{array}$} \\
\hline June $(6 / 21 / 01-6 / 30 / 01)$ & $14.5 \mathrm{mph}$ \\
\hline July 2001 & $13.4 \mathrm{mph}$ \\
\hline August 2001 & $13.5 \mathrm{mph}$ \\
\hline September 2001 & $13.4 \mathrm{mph}$ \\
\hline October 2001 & $17.1 \mathrm{mph}$ \\
\hline November 2001 & $18.2 \mathrm{mph}$ \\
\hline December 2001 & $18.6 \mathrm{mph}$ \\
\hline January 2002 & $16.8 \mathrm{mph}$ \\
\hline February 2002 & $17.7 \mathrm{mph}$ \\
\hline $\operatorname{March}(3 / 1 / 02-3 / 7 / 02)$ & $19.8 \mathrm{mph}$ \\
\hline Overall Average (6/21/01 - 3/7/02) & $16.1 \mathrm{mph}$ \\
\hline & $18.35 \mathrm{mph}$ at $50 \mathrm{~m}$ \\
\hline
\end{tabular}




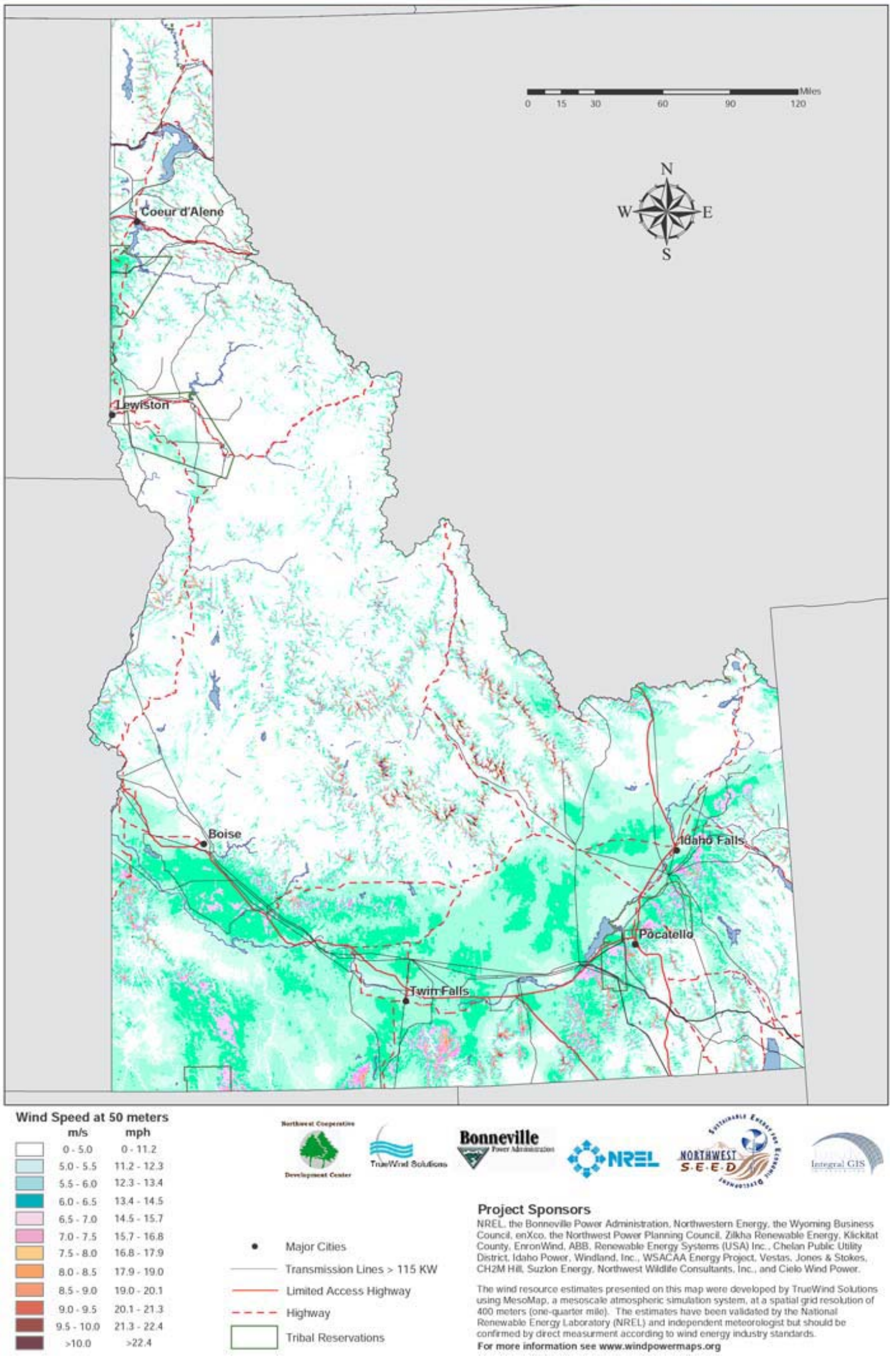




\subsubsection{Overview of Current Wind Resource Characterizations at Duck Valley}

The $138 \mathrm{kVa}$ transmission line to be constructed by RREC will originate at the $\mathrm{C} \mathrm{J}$ Strike Reservoir near Bruneau, Idaho and continue south along Highway 51 for approximately 56 miles to a substation south of Riddle, Idaho and one mile north of the northern border of the Duck Valley Reservation. This line will be lightly loaded for many years $(\sim 10 \%)$ and provides a "gateway" for exporting wind-generated power to regional markets. The transmission line's proposed route from Bruneau to the Duck Valley Reservation traverses a "banana shaped" expanse of high, well exposed, open range land, much of which is Federal land [either the Bureau of Land Management or the US Air Force (the Mountain Home Air Force Base is north and west of Bruneau)].

The primary objective of the Study with regards to wind resource characterization was to gather new wind data on high ground at the northern end on the Reservation where, if wind power were found to be feasible, a wind farm project could be interconnected to the substation to be built at Riddle. In addition to the continuation of data collection on the original Duck Valley/NREL site, two new wind farm sites were scouted and 20 meters towers provided by the Idaho Department of Water Resources (IDWR) were installed, one at the "Miller Creek" site and the other at the "Antelope Springs" site.

Directly south of the proposed substation at Riddle is the Owyhee Valley and the town of Owyhee, where most of the Tribes' population and infrastructure is based. To the southeast of the Riddle substation and directly east of the Tribal Headquarters is the Miller Creek site - high, well exposed treeless land $(\sim 6400$ to 6660 feet) that is a continuation of the area's "banana-shaped" topographic feature. The Miller Creek site is a gradually sloping (up to the south) site, sits about 1000 feet above the Owyhee Valley situated to the west, and could support tens of MWs of wind power. It is presently difficult to reach the site as the area is accessed primarily by 4-wheel drive vehicles, but improved roads could be built from Highway 51 . The distance from the Miller Creek site to the proposed substation at Riddle is about 5-6 miles.

On the west side of the Owyhee Valley at 5700 feet elevation (300 to 400 feet above the Owyhee Valley) is the Antelope Springs site. This site also a relatively high, well exposed, treeless location that is dissected by a gravel road that is well maintained by a major pipeline company. The distance from the Antelope Springs site to the proposed substation at Riddle is about 10-12 miles.

In addition to the Miller Creek and Antelope Springs sites, the Idaho Department of Water Resources installed an anemometer on an existing tower at a remote US Air Force communications site at Grasmere, Idaho, which is situated on high exposed ground north of the Owyhee Valley and north of the Duck Valley Reservation. The Grasmere site is situated approximately mid point on the "banana-shaped" topographic feature and is a very useful point of comparison to the two Duck Valley wind data collection sites (designated by the triangles in the map below). 


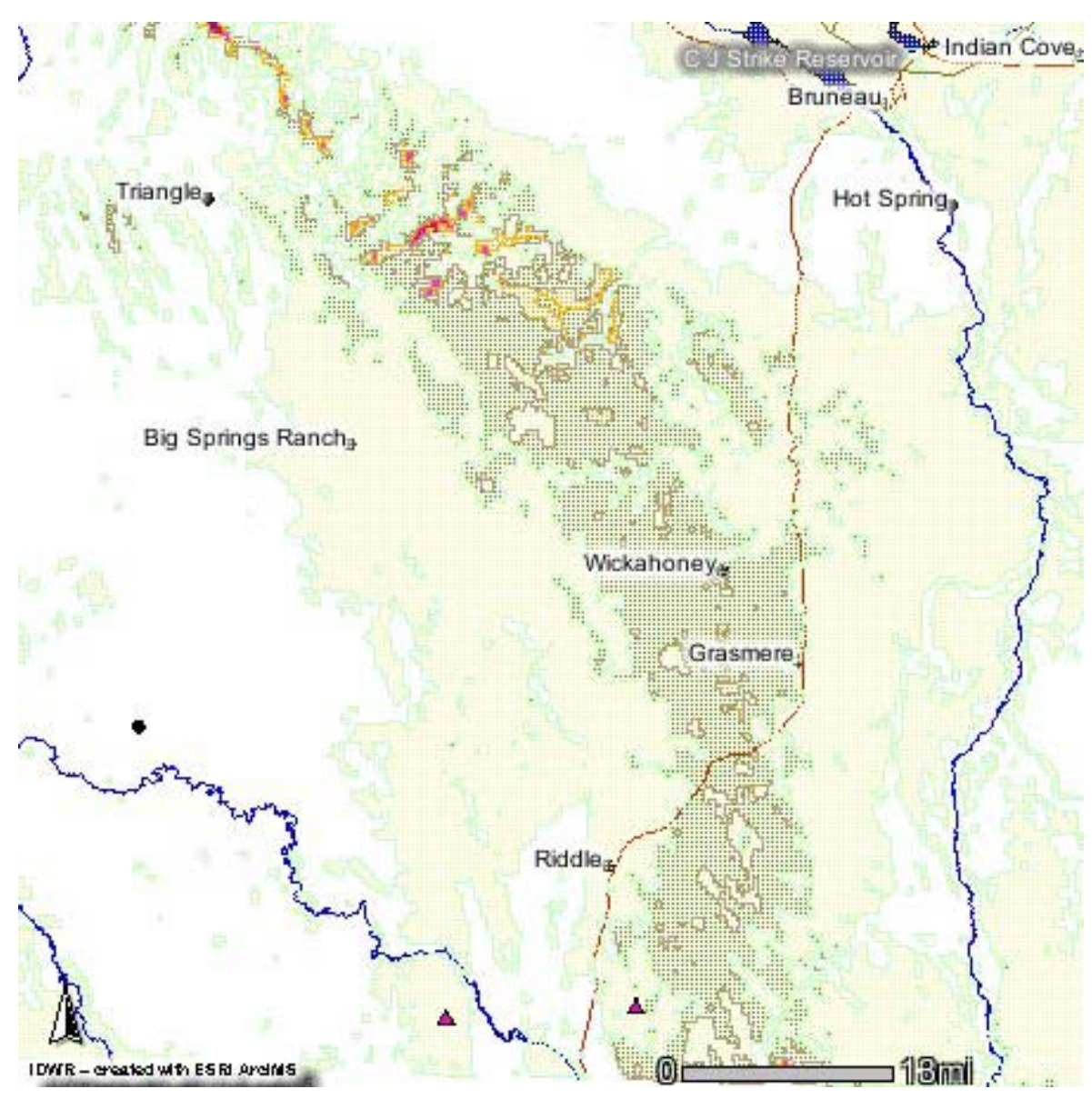

\subsubsection{Results of Wind Resource Data Collection at Duck Valley}

Data collected from the Idaho Department of Water Resources anemometers was processed by the Idaho National Environmental Engineering Laboratory (INEEL). The following tables present the average monthly winds speeds at 20 meters for the Miller Creek, Antelope Springs, and Grasmere data collection sites for the period October 2003 to September 2004. This data indicates that the Miller Creek and Grasmere sites have comparable annual average wind speeds of 13.8 and $14.1 \mathrm{mph}$, respectively [which would place both sites in the Class 4 category ("Good" rating)], while the annual average wind speed at Antelope Springs site is considerably less at $11.4 \mathrm{mph}$ [which would place the site in the Class 2 category ("Poor" rating).

"Wind Analysis Summary Reports" provided by INEEL and shown in Appendix B provide prevailing wind direction, power output from a candidate wind turbine, and frequency distribution data for the three sites. The average wind direction for all three sites is from the southwest (Miller Creek: 202 degrees). INEEL estimates that the gross capacity factor for a $65 \mathrm{~m}$ tall $1.5 \mathrm{MW}$ turbine at the Miller Creek site is $32 \%$ (scaled up from $20 \mathrm{~m}$ assuming average wind shear), while the same turbine would have a slightly better (33-36\%) gross capacity factor at the Grasmere site.

The Duck Valley Tribes are continuing to collect and analyze wind resource data for the Miller Creek and Antelope Springs for another 6 months (until approximately June 2005) and has submitted an application to NREL for a 50 meter tower to be placed at the Miller Creek site and operated for at least one additional year. 


\begin{tabular}{|c|c|}
\hline \multicolumn{2}{|c|}{$\begin{array}{c}\text { Duck Valley Miller Creek Average Wind Speeds } \\
\text { Site \#0131 } \\
\text { (66 ft. }(20 \mathrm{~m}) \text { tower) } \\
\text { N. } 42 \text { deg. 3.728', W. 116 deg. 4.690' } \\
\text { Elevation }-6591 \mathrm{ft} .\end{array}$} \\
\hline October $(10 / 15 / 03-10 / 31 / 03)$ & $13.6 \mathrm{mph}$ \\
\hline November 2003 & $15.2 \mathrm{mph}$ \\
\hline $\begin{array}{l}\text { December } 2003 \text { ( } 2 \text { days of iced data taken } \\
\text { out) }\end{array}$ & $16.0 \mathrm{mph}$ \\
\hline $\begin{array}{l}\text { January } 2004 \text { ( } 2.5 \text { days of iced data taken } \\
\text { out) }\end{array}$ & $13.6 \mathrm{mph}$ \\
\hline $\begin{array}{l}\text { February } 2004 \text { ( } 1.5 \text { days of iced data } \\
\text { taken out) }\end{array}$ & $14.5 \mathrm{mph}$ \\
\hline March 2004 & $14.2 \mathrm{mph}$ \\
\hline April 2004 & $12.6 \mathrm{mph}$ \\
\hline May 2004 & $13.3 \mathrm{mph}$ \\
\hline June 2004 & $13.6 \mathrm{mph}$ \\
\hline July 2004 & $12.5 \mathrm{mph}$ \\
\hline August 2004 & $13.1 \mathrm{mph}$ \\
\hline September 2004 & $12.2 \mathrm{mph}$ \\
\hline October 2004 & $13.4 \mathrm{mph}$ \\
\hline November $(11 / 1 / 04-11 / 16 / 04)$ & $11.4 \mathrm{mph}$ \\
\hline Overall Average (10/15/03 - 10/15/04) & $13.6 \mathrm{mph}$ \\
\hline & $15.5 \mathrm{mph}$ at $50 \mathrm{~m}$ \\
\hline
\end{tabular}

\begin{tabular}{|c|c|}
\hline \multicolumn{2}{|c|}{$\begin{array}{c}\text { Duck Valley Antelope Springs Average Wind Speeds } \\
\underline{\text { Site } \# 0215} \\
\text { (66 ft. }(20 \mathrm{~m}) \text { tower) } \\
\text { N. } 42 \text { deg. 2.905', W. 116 deg. 18.501' } \\
\text { Elevation }-5727 \mathrm{ft} \text {. }\end{array}$} \\
\hline October $(10 / 14 / 03-10 / 31 / 03)$ & $11.0 \mathrm{mph}$ \\
\hline November 2003 & $12.0 \mathrm{mph}$ \\
\hline December 2003 & $13.0 \mathrm{mph}$ \\
\hline $\begin{array}{l}\text { January } 2004 \text { (1 day of iced data taken } \\
\text { out) }\end{array}$ & $12.7 \mathrm{mph}$ \\
\hline February 2004 & $11.7 \mathrm{mph}$ \\
\hline March 2004 & $10.9 \mathrm{mph}$ \\
\hline April 2004 & $10.7 \mathrm{mph}$ \\
\hline May 2004 & $11.4 \mathrm{mph}$ \\
\hline June 2004 & $11.3 \mathrm{mph}$ \\
\hline July 2004 & $10.2 \mathrm{mph}$ \\
\hline August 2004 & $11.1 \mathrm{mph}$ \\
\hline September 2004 & $9.9 \mathrm{mph}$ \\
\hline October 2004 & $10.3 \mathrm{mph}$ \\
\hline
\end{tabular}




\begin{tabular}{|l|c|}
\hline November $(11 / 1 / 04-11 / 16 / 04)$ & $9.0 \mathrm{mph}$ \\
\hline Overall Average (10/14/03-10/14/04) & $\mathbf{1 1 . 2} \mathbf{~ m p h}$ \\
\hline & $12.8 \mathrm{mph}$ at $50 \mathrm{~m}$ \\
\hline
\end{tabular}

\begin{tabular}{|l|}
\hline \multicolumn{2}{|c|}{$\begin{array}{c}\text { Grasmere Station, Mountain Home AFB Average Wind Speeds } \\
\text { Site } 77001\end{array}$} \\
N. 42 deg. 18', W. 115 deg. 59' (approximate) \\
Elevation - 5940 ft. (approximate)
\end{tabular}

\subsubsection{Next Steps for Duck Valley Wind Development Efforts}

Before efforts to develop its wind resources can be aggressively pursued, the Duck Valley Tribes must "firm up" their wind resource. The one-year wind speed data results from the Miller Creek site are very encouraging, as are the results from the Grasmere site to the north of the Reservation. However, both sites have been instrumented with anemometers at approximately $20 \mathrm{~m}$, far below the hub height $(60+$ meters) of modern, large-scale wind turbines. While extrapolation of wind speeds from $20 \mathrm{~m}$ to wind turbine hub height is frequently done using rules of thumb (e.g. the 1/7 power law) and is a useful exercise, such extrapolations do not provide sufficient confidence in multi-year wind speeds (and direction) to justify the commitment of significant financial resources to develop a wind farm.

Further, extrapolation rules of thumb for determining wind shear at turbine height (say 60-80 m) may not be appropriate for the Miller Creek site as it sit atop a large mesa-like topographic feature. It is entirely plausible that there is considerable acceleration of wind speed on top of the mesa as southwesterly air flow rises up and over the edge of the land form and forms a "zone of compression" above the mesa. The characteristics (height, thickness, etc.) of this "zone of compression" are not currently understood.

To illustrate the importance of understanding the wind resource at turbine height, wind resource data for the Miller Creek site was used in a preliminary analysis of a $50 \mathrm{MW}$ wind farm using the RETScreen 
Wind Energy Model, with the model's output also shown in Appendix B. Annual average wind speeds of $13.8 \mathrm{mph}(6.2 \mathrm{~m} / \mathrm{s})$ were entered into the model, along with the power output profile from a utility scale wind turbine (1.65 MW) and a wind shear exponent value. Three separate scenarios were run using: 1$)$ wind shear exponent of 0.14 (based on the $1 / 7$ power law), 2) wind shear exponent of 0.20 , and 3 ) wind shear exponent of 0.26 .

For each of the three scenarios the model estimated electricity production from a hypothetical wind farm using 30 turbines (accounting for array interaction and other system losses) and plant capacity factor. The RETScreen model was also used to generate an estimate of costs for the hypothetical $50 \mathrm{MW}$ wind farm based on recently built wind farm projects elsewhere and provided the basis for a preliminary financial analysis shown in Appendix B.

The results of the modeling are summarized in the table below.

\begin{tabular}{|c|c|c|c|c|}
\hline \multicolumn{6}{|c|}{ EFFECT OF WIND SHEAR ASSUMPTIONS ON FEASIBILITY OF 50 MW WIND FARM } \\
\hline Wind Shear Exponent & $\begin{array}{c}\text { Electricity } \\
\text { Delivered } \\
\text { (MWh) }\end{array}$ & $\begin{array}{c}\text { Wind Plant } \\
\text { Capacity } \\
\text { Factor }\end{array}$ & $\begin{array}{c}\text { Project Cost } \\
\text { (\$ Million) }\end{array}$ & $\begin{array}{c}\text { Pretax IRR } \\
\text { and ROI } \\
\text { (\%) }\end{array}$ \\
\hline 0.14 & 102,635 & 0.24 & 47.3 & 16.6 \\
\hline 0.20 & 118,650 & 0.27 & 47.3 & 21.7 \\
\hline 0.26 & 134,903 & 0.31 & 47.3 & 26.7 \\
\hline
\end{tabular}

This table indicates the importance of understanding more definitively the wind resource at or near the hub height of the turbines to be used in a wind project. If standard rules of thumb are applied $(0.14$ wind shear exponent yielding a wind speed at hub height of $7.3 \mathrm{~m} / \mathrm{s}$ ), a $50 \mathrm{MW}$ wind farm at the Miller Creek site looks financially attractive given the use of low cost (3\%), long term (30 years or more) financing from USDA RUS. The electricity output and financial attractiveness of the $50 \mathrm{MW}$ wind farm project would be even greater if the average wind speed at turbine height were empirically determined by field measurements to be $7.9 \mathrm{~m} / \mathrm{s}(0.20$ wind shear exponent $)$.

As part of a proposed Phase II Duck Valley Wind Farm Project Feasibility Study, the Duck Valley Tribes will seek additional funding from the DOE Tribal Energy Program to:

1) install one or more 50 meter anemometer towers at the Miller Creek and Grasmere sites to collect wind resource data at heights that are better matched with utility-scale wind turbines; and

2) deploy SODAR equipment to collect shorter term data (in conjunction with the longer term data from the taller towers) to better characterize vertical wind shear at multiple data points on the prospective wind farm sites.

Given the timing of the completion of the RREC transmission line and substation in 2007, Duck Valley will use the period from 2005 to 2007 to conduct this additional round of wind resource data collection so that wind farm development, if proven to be feasible, can proceed in the 2007/2008 timeframe.

\subsection{Solar Power}

Photovoltaic modules (also called panels) convert direct sunlight to direct current electricity. There are two basic types of photovoltaic (PV) cells: crystalline silicon and thin film. PV modules typically have a peak power output of 50 to 300 watts. Modules can be assembled into arrays, which can vary from just two modules for a small residential system to hundreds of modules for a utility-scale system of $100 \mathrm{~kW}$ or more. The PV modules are the fundamental, but not the only, components of a PV system. Various 
mounting brackets, supports, and hardware are required to position and hold the modules. An inverter is required to convert the modules' direct current (DC) output to the grid's alternating current (AC) standard. A step-up transformer may be required to increase the voltage to that of the grid. The costs of these non-module, or balance of system (BOS), components are significant. They make up almost half of total system costs.

At the benchmark retail price of $\$ 7,000$ to $\$ 10,000$ per kilowatt, PV systems yield electricity at a cost of 25 to 40 cents per kilowatt-hour, roughly four to six times the typical price a grid connected Duck Valley residential customer pays for power. However, PV system can become immediately competitive where utility lines are not available. Packaged PV systems for remote applications rated at 1 to $2 \mathrm{~kW}$ may cost $\$ 10,000$ to $\$ 20,000$, which is far less than the cost to extend the electric grid $(\$ 25,000+$ per mile). PV systems can benefit from economies of scale for larger projects. Costs per kilowatt can be significantly reduced for systems in the $10+\mathrm{kW}$ range (approximately $\$ 5-7$ per $\mathrm{Wp}$ ) compared to the smaller 1-2 $\mathrm{kW}$ systems $(\$ 10 / \mathrm{Wp}$ or more $)$.

As the Duck Valley Reservation is situated in a high, semi-arid location, it has a relatively high average solar radiation resource of $5.5-6.0 \mathrm{kWh} / \mathrm{m} 2 /$ day (flat plate, facing south, latitude tilt). The use of solar photovoltaic systems is primarily an electric supply option for electric loads (e.g. irrigation pumping, communication equipment, etc.) that are a mile or more off the existing distribution system. A prime example of the use of PV systems in the area is the $75 \mathrm{kWp} \mathrm{PV-diesel} \mathrm{hybrid} \mathrm{system} \mathrm{that} \mathrm{provides} \mathrm{power}$ to the off-grid US Air Force communication facility at Grasmere.

While the distribution system serving the Reservation is now capacity constrained and relatively unreliable and PV systems could be used to meet (or partially meet) individual on-grid loads or support the local distribution network, use of on-grid PV systems at Duck Valley are not expected to be cost competitive in the near future as the development of the new transmission line and substation serving the Reservation is scheduled for 2007 and the region has one of the lowest costs of electricity in the country $(\$ 0.06 / \mathrm{kWh})$.

\subsection{Fuel Cells}

Fuel cells are an emerging energy technology that may be a cost effective distributed generation option within 5 to 10 years. Fuel cells are electro-chemical devices that convert a hydrogen based fuel (such as propane or natural gas) into electricity with virtually no emissions other than heat and water vapor. Even the waste heat might be utilized for water heating or space heating. Fuel cells are being developed by a growing number of North American companies in sizes for individual homes, automobiles (to replace the internal combustion engine with an electrical power source for electric vehicles), medium to large scale commercial facilities, and smaller central plant generating stations.

The most likely near term applications for fuel cell applications on the Duck Valley Reservation would be building-sited systems that would be fueled by propane. The system economics of fuel cell/propane systems would need to be compared to that of grid power, micro-turbine/propane systems, PV systems, and utility-scale wind systems, but it is believed that once fuel cells production ramps up in the next decade, fuel cells could represent a viable power option for the Duck Valley Reservation.

Fuel cells also may have a future relationship to wind farm developments that may be pursued by the Duck Valley Tribes. There is considerable interest among energy planners in using electricity generated from wind farms to produce hydrogen gas (via electrolysis of water). It is conceivable that electricity from a Duck Valley wind farm could be sold to off-reservation markets via the new transmission line, with some portion of the electricity being devoted to a local electrolyis facility that would "manufacture" hydrogen for use with fuel cells on the Reservation. 


\subsection{SUMMARY OF BENEFITS/BARRIERS AND IMPLEMENTATION REQUIREMENTS}

The primary objective of A Feasibility Study of Sustainable Distributed Generation Technologies to Improve the Electric System on the Duck Valley Reservation was to address the reliability and deliverability of the electric distribution system on the Reservation so that economic development initiatives can continue to be pursued. Secondary objectives of the Study that also are supportive of economic development included:

a reduction in energy-related expenditures by Tribal businesses and households;

$\square$ creation of energy-related jobs on the Reservation; and

$\square$ preservation of the environment on the Reservation.

\subsection{Benefits and Barriers}

The economic benefits that can result from deploying DG technologies assessed in the Study include:

$\square$ the distribution system capacity $(60+\mathrm{kW})$ that is "freed up" by lighting efficiency upgrades alone, enabling other loads (i.e. new economic development initiatives) to be accommodated;

$\square$ the operating cost savings for electrical end users; and

$\square$ the local jobs created to install, operate, and maintain DG systems, particularly if a large scale wind farm project is built.

There are barriers to DG technology deployment at Duck Valley that will need to be addressed. First, DG technologies in general may be perceived as a threat to the local electric provider, RREC. However, in the situation at Duck Valley where RREC has been unable to accommodate additional load growth on the Reservation without major system upgrades, RREC will likely view the use of energy efficiency and DG technologies as a strategy to meet its obligation to provide reliable electric service to Duck Valley in a cost effective and environmentally-sensitive manner. Further, since RREC is the primary partner in the new $138 \mathrm{kVa}$ line that will serve the Reservation by 2007, RREC may be extremely motivated to support the development of a wind farm project in partnership with the Duck Valley Tribes in order to amortize an otherwise lightly loaded transmission line.

A second barrier to DG technology deployment at Duck Valley is the region's low cost of electricity. The cost of electricity to current end users on the Reservation is well below the national average, due in large part to region's hydropower generation. Justifying small scale DG technologies on the Duck Valley Reservation based on electricity $(\mathrm{kWh})$ savings alone will be difficult. However, as there is upward pressure on electricity costs in the Pacific Northwest and elsewhere, large-scale wind projects using above average wind resources (such as those found at Duck Valley) can be competitive with grid power when Federal, state, and buyer (i.e. green tags) production incentives are considered.

\subsection{Required Steps for Project Implementation}

The required steps for pursuing the implementation of the two primary energy initiatives that have emerged as a result of this Study are:

\section{Duck Valley Wind Farm Project}

Step 1. Apply for Phase II Funding (2 Years) from the 2005 DOE Tribal Energy Program for the following activities:

Installation of one to two 50m anemometer tower at the Miller Creek site on the Reservation; 
Deployment of SODAR on a short term basis (6 months) to supplement (i.e. vertical wind shear profiles) the fixed $50 \mathrm{~m}$ tower data at multiple data points across the wind farm sites;

- Conduct environmental (including avian study) and cultural assessments of Miller Creek site;

Conduct preliminary design of a wind farm project (50 MW or higher) on the preferred local site, including turbine layout and transmission interconnection;

- Prepare detailed energy production and cost estimates for the wind farm project; and

- Perform financial modeling based on prevailing loan rates, production incentives, and other factors.

Step 2. Meet with BLM and USAF Regarding Access/Restrictions to Lands North of the Reservation

Step 3. Meet with RREC and Other Partners Re: Access to 138kV Line for Export Use

Step 4. Meet with USAF and Other Regional Electricity Users Re: Power Purchase Interest

Step 5. Review Funding/Financing Sources:

$\square$ the States of Nevada and/or Idaho;

U USDA [economic development programs, Rural Utility Service (which makes low cost, long term loans available for rural electric organizations)];

- Departments of Commerce and HUD (rural economic development programs, community development block grants, etc.)

口 Department of Energy (from "project development" funds available from subsequent Renewable Energy Development on Tribal Lands solicitations)

Step 6. Meet w/ Potential Project Development Partners (if required)

Step 7. Complete the Activities from the DOE Phase II Study (see Step 1)

If DOE funding is made available in a timely manner by late 2005, these steps can be accomplished between 2005 and 2007, with construction start-up of a wind farm project possible in late 2007 or 2008 .

\section{Duck Valley Re-Lighting Project}

The economics of the proposed relighting strategies are compelling enough for most of the buildings audited that immediate, economically justified action could be taken by the managing entities (i.e. Duck Valley Tribal Government, Owyhee School, IHS, etc.). A Duck Valley Re-Lighting Project could also be pursued in a collaborative manner among the various managing entities so that lighting equipment is purchased, at least initially, in bulk (i.e. electronic ballasts and T8 lamps) and facility maintenance personnel can share information on installation strategies and procedures.

Step 1. Explore Interest from RREC and States of Idaho/Nevada in Project

Step 2. Present Information to Building/Program Managers and Facility Maintenance Personnel

If Consensus is to Pursue Retrofits Individually

Step 3. Commence Retrofits

If Consensus is to Pursue Retrofits Collaboratively

Step 3. Seek Funding Support (e.g. HUD RHED Program or BPA/NW SEED Programs) 
Step 4. Buy Equipment in Bulk

Step 5. Commence Retrofits 


\section{APPENDIX A LIGHTING INVENTORY DATA FOR DUCK VALLEY BUILDINGS \\ Lighting System Inventory for Major Buildings \\ on Duck Valley Indian Reservation}

\section{Hospital}

All fluorescent lighting systems operate at $277 \mathrm{~V}$.

Typical lamp/ballast is F40T12CW lamp (some F34T12CW) with V2S40TP Advance magnetic ballast. U-bend lamp is F40CW-U-6 super cool white

8' T12 lamps only used in shop (F96T12CWWM (single pin)

Backup diesel generator rated at $350 \mathrm{~kW} \max$ (8-10 system outages/year; 1 hour average outage)

30,000 gallon propane tank ( $\sim \$ 0.46 /$ gallon in bulk)

\section{Hallways/Outpatient Waiting}

42 2x2 2 lamp recessed fixtures with acrylic lens with U-bend T12 CW lamps

( $\sim 15$ more $2 \times 2$ fixtures are permanently disconnected because there was too much light in the hallways)

$12 \times 44$ lamp recessed fixture with T12 lamps over the receptionist work area

Dental Clinic (Room 6)

12 2x4 4 lamp recessed fixtures with acrylic lens with T12 CW lamps (bright but appropriate)

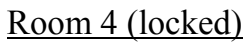

$\underline{\text { Pharmacy }}$

$102 \times 44$ lamp recessed fixtures with acrylic lens with T12 CW lamps (bright but appropriate)

Pharmacist Office

$22 \times 44$ lamp recessed fixtures with acrylic lens with T12 CW lamps

Men's Restroom (at top of stairs)

1 4"x4' 2 lamp fixture with T12 CW lamps

1 4”x2' 2 lamp fixture with T12 CW lamps (above mirror)

Women's Restroom (at top of stairs)

1 4"x4' 2 lamp fixture with T12 CW lamps

1 4”x2' 2 lamp fixture with T12 CW lamps (above mirror)

$\underline{\text { Room } 87 \text { Suite }}$

$142 \times 44$ lamp recessed fixtures with acrylic lens with T12 CW lamps

$12 \times 22$ lamp recessed fixtures with acrylic lens with U-bend T12 CW lamps 
$\underline{\text { Laboratory }}$

$152 \times 44$ lamp recessed fixtures with acrylic lens with T12 CW lamps

$\underline{\text { Lab Hallway }}$

$82 \times 22$ lamp recessed fixtures with acrylic lens with U-bend T12 CW lamps

Blood Bank (Room 80)

$42 \times 44$ lamp recessed fixtures with acrylic lens with T12 CW lamps

Radiology (Room 70)

14 2x4 4 lamp recessed fixtures with acrylic lens with T12 CW lamps

$\underline{\text { Room } 60)}$

4 2x4 4 lamp recessed fixtures with acrylic lens with T12 CW lamps

Emergency Hallway

$62 \times 22$ lamp recessed fixtures with acrylic lens with U-bend T12 CW lamps

Emergency Surgery (Room 175)

10 2x4 4 lamp recessed fixtures with acrylic lens with T12 CW lamps

Housekeeping (Room 64)

9 18"x4' 2 lamp surface mounted fixtures with acrylic lens with T12 CW lamps

Linen

2 2x4 4 lamp recessed fixtures with acrylic lens with T12 CW lamps

$\underline{\text { Room } 77}$

2 2x4 4 lamp recessed fixtures with acrylic lens with T12 CW lamps

2 2x4 2 lamp recessed fixtures with acrylic lens with T12 CW lamps

Supply (Room 173)

20 18”x4' 2 lamp suspended fixtures with T12 CW lamps

EMT Storage

6 18'x4' 2 lamp suspended fixtures with T12 CW lamps

EMT Vestibule

$12 \times 22$ lamp recessed fixtures with acrylic lens with U-bend T12 CW lamps 
Mechanical

15 6"x4' 2 lamp suspended channel fixtures with T12 CW lamps

$\underline{\text { Staff Lounge/Cafeteria }}$

$42 \times 44$ lamp recessed fixtures with acrylic lens with T12 CW lamps (w/ 4 others disconnected)

$\underline{\text { Kitchen }}$

21 12"x4' 2 lamp surface mounted fixtures with acrylic lens and T12 CW lamps

$22 \times 44$ lamp recessed fixtures with acrylic lens with T12 CW lamps

2 2x4 2 lamp recessed fixtures with acrylic lens with T12 CW lamps

2 2x2 2 lamp surface mounted fixtures with acrylic lens with U-bend T12 CW lamps

$\underline{\text { Men's Restroom }}$

2 4"x4' 2 lamp fixture with T12 CW lamps

1 4”x2' 2 lamp fixture with T12 CW lamps (above mirror)

$\underline{\text { Women's Restroom }}$

1 4"x4' 2 lamp fixture with T12 CW lamps

1 4”x2' 2 lamp fixture with T12 CW lamps (above mirror)

Optometrist

$22 \times 44$ lamp recessed fixtures with acrylic lens with T12 CW lamps

Optometrist Hallway/Reception

$52 \times 22$ lamp recessed fixtures with acrylic lens with U-bend T12 CW lamps

3 1x4 2 lamp surface mounted fixtures with T12 CW lamps

Optometrist Waiting

$42 \times 42$ lamp recessed fixtures with acrylic lens with T12 CW lamps

Conference Room (behind optometrist waiting room)

$102 \times 44$ lamp recessed fixtures with acrylic lens with T12 CW lamps

[too much light (used to be a birthing room); 4 lamp ballast w/ 2 lamps is recommended]

$\underline{\text { Counselor Room/Storage Room }}$

$42 \times 42$ lamp recessed fixtures with acrylic lens with T12 CW lamps

Patient Room (Typical; 12 in total)

2 6"x4' 2 lamp wall mounted fixtures with T12 CW lamps 
1 6”x2' 2 lamp wall mounted fixture with T12 CW lamps

$\underline{\text { Medical Staff Counter }}$

8 1x4 2 lamp surface mounted fixtures with acrylic lens with T12 CW lamps

Nurse's Locker Room

2 1x4 2 lamp surface mounted fixture with acrylic lens with T12 CW lamps

1 6”x2’ 2 lamp wall mounted fixture with $\mathrm{T} 12 \mathrm{CW}$ lamps (above mirror)

Nurses Office

2 2x4 4 lamp recessed fixtures with acrylic lens with T12 CW lamps

1 6"x4' 2 lamp surface mounted fixture with acrylic lens with T12 CW lamps

Nourishment (Room 127)

$12 \times 44$ lamp recessed fixtures with acrylic lens with T12 CW lamps

Linen (soiled)

$22 \times 44$ lamp recessed fixtures with acrylic lens with T12 CW lamps

$\underline{\text { Staff Locker }}$

$12 \times 22$ lamp recessed fixtures with acrylic lens with U-bend T12 CW lamps

Storage (Rooms 129 and 132)

$62 \times 44$ lamp recessed fixtures with acrylic lens with T12 CW lamps

$\underline{\text { Tub Room }}$

$12 \times 42$ lamp recessed fixtures with acrylic lens with T12 CW lamps

$\underline{\text { Dental Office }}$

$62 \times 44$ lamp recessed fixtures with acrylic lens with T12 CW lamps

Health Information/Records (Room 46)

12 2x4 4 lamp recessed fixtures with acrylic lens with T12 CW lamps

Behavioral Health (Room 16)

2 2x4 4 lamp recessed fixtures with acrylic lens with T12 CW lamps

$12 \times 22$ lamp recessed fixtures with acrylic lens with U-bend T12 CW lamps

Conference Room (Room 34)

$62 \times 44$ lamp recessed fixtures with acrylic lens with T12 CW lamps 
Mental Health (Room 20)

$82 \times 44$ lamp recessed fixtures with acrylic lens with T12 CW lamps

$\underline{\text { Substance Abuse (Room 33) }}$

$32 \times 44$ lamp recessed fixtures with acrylic lens with T12 CW lamps

Office (Room 22)

$22 \times 44$ lamp recessed fixtures with acrylic lens with T12 CW lamps

Office (Room 23)

2 2x4 4 lamp recessed fixtures with acrylic lens with T12 CW lamps

Office (Room 27)

2 2x4 4 lamp recessed fixtures with acrylic lens with T12 CW lamps

Office (Room 29)

$12 \times 42$ lamp recessed fixtures with acrylic lens with T12 CW lamps

$\underline{\text { Storage (Room 31) }}$

$12 \times 42$ lamp recessed fixtures with acrylic lens with $\mathrm{T} 12 \mathrm{CW}$ lamps

Soiled Utility (Room 32)

$12 \times 42$ lamp recessed fixtures with acrylic lens with T12 CW lamps

Exam Rooms (4 in total)

$22 \times 44$ lamp recessed fixtures with acrylic lens with T12 CW lamps

Allergy

2 2x4 4 lamp recessed fixtures with acrylic lens with T12 CW lamps

Inpatient Nursing System

4 1x4 2 lamp surface mounted fixtures with acrylic lens with T12 CW lamps

$72 \times 22$ lamp recessed fixtures with acrylic lens with U-bend T12 CW lamps

Waiting Room Office

$22 \times 44$ lamp recessed fixtures with acrylic lens with T12 CW lamps

Maintenance Shop (lower level)

818 "x8' suspended fixtures with F96T12 lamps

Hallway (lower level)

$142 \times 42$ lamp recessed fixtures with acrylic lens with T12 CW lamps 
Workout Room (lower level)

10 6"x4' 2 lamp fixtures with clear lens with T12 CW lamps

$\underline{\text { West Entry Vestibule (lower level) }}$

$12 \times 22$ lamp recessed fixtures with acrylic lens with U-bend T12 CW lamps

Men's Restroom

5 1x4 2 lamp surface mounted fixture with $\mathrm{T} 12 \mathrm{CW}$ lamps

Women's Restroom

5 1x4 2 lamp surface mounted fixture with T12 CW lamps

$\underline{\text { Bottom of Stairs (lower level) }}$

$12 \times 22$ lamp recessed fixtures with acrylic lens with U-bend T12 CW lamps

$\underline{\text { Rooms } 18,20,21,22,23,24,25,26,27 \text { (lower level) }}$

$342 \times 43$ lamp recessed fixtures with acrylic lens with T12 CW lamps

$\underline{\text { Room } 109 \text { (lower level) }}$

8 2x4 4 lamp surface mounted fixtures with acrylic lens with T12 CW lamps

Storage - Room 109 (lower level)

12 18”x4' 2 lamp suspended fixtures with T12 CW lamps

\section{Total}

$\underline{4 \text { foot fixtures }}$

4 lamp: 176

3 lamp: 34

2 lamp: 164

2 foot fixtures (u-bends)

2 lamp: 76

8 foot fixtures

2 lamp: 8

\section{Tribal Headquarters}

\section{Exterior-West Entry}

6 12"x12" medium base incandescent fixture (60-75W lamps) (on 24 hours per day!)

(fixture will easily accommodate a screw-in CFL of 18-20W)

(fixture lens need to be removed and washed)

Lobby

17 12"x12" medium base incandescent fixture (60-75W lamps) 


\section{Council Chambers}

2312 "x12" medium base incandescent fixtures (60-75W lamps)

4 pedestal mounted open fixtures with very large incandescent bulb ( $\sim 300 \mathrm{~W}$ with large base)

(use a high wattage CFL with large base or use new "low bay" metal halide fixtures)

Hallway (north-south)

2512 "x12" medium base incandescent fixtures (60-75W lamps)

Hallway-Copy

$22 \times 44$ lamp recessed fixtures with acrylic lens with T12 CW lamps (some F40CW, some F34CW)

$42 \times 22$ lamp fixtures with acrylic lens with U-bend CW lamps

$\underline{\text { South Offices }}$

$252 \times 44$ lamp recessed fixtures with acrylic lens with T12 CW lamps

$\underline{\text { South Entrance }}$

2 12"x12" medium base incandescent fixtures (60-75W lamps)

Men's Restroom

112 "x12" medium base incandescent fixture (60-75W lamps)

2 1x4 2 lamp wall mounted fixtures above mirrors (needs new fixtures w/ acrylic lens)

$\underline{\text { Women's Restroom }}$

112 "x12" medium base incandescent fixture (60-75W lamps)

$21 \times 42$ lamp wall mounted fixtures above mirrors (needs new fixtures w/ acrylic lens)

Business Council

$42 \times 22$ lamp fixtures with acrylic lens with U-bend CW lamps

Chairman's Office

4 6”x4' 2 lamp surface mounted fixtures with acrylic lens with T12 CW lamps

Business Council Conference Room

$122 \times 44$ lamp recessed fixtures with acrylic lens with T12 CW lamps

$\underline{\text { Reception }}$

$22 \times 44$ lamp recessed fixtures with acrylic lens with T12 CW lamps

Men's Restroom (north end)

2 1x4 2 lamp wall mounted fixtures above mirrors (needs new fixtures w/ acrylic lens) 
Women's Restroom (north end)

2 1x4 2 lamp wall mounted fixtures above mirrors (needs new fixtures w/ acrylic lens)

North Office

22 lamp 6" surface mounted fixture with no lens (nneds new 2 lamp 6" wrap fixture with acrylic lens)

East Offices

26 2x4 4 lamp recessed fixtures with acrylic lens with T12 CW lamps

East Office Hall

$42 \times 22$ lamp fixtures with acrylic lens with U-bend CW lamps

$\underline{\text { Basement }}$

22 2x4 4 lamp recessed fixtures with acrylic lens with T12 CW lamps

Modular Building (East)

$262 \times 42$ lamp recessed fixtures with acrylic lens with T12 CW lamps

3 6”x4' 2 lamp wall mount fixtures with acrylic lens with T12 CW lamps (hallways)

Modular Building (West)

New 2 lamp recessed fixtures with 12 cell egg crate aluminum lens with Philips F32T8TO735 lamps (no retrofit)

Total

60-75W Incandescent Fixtures: $\quad 75$

$\underline{4 \text { foot fixtures }}$

4 lamp: 89

2 lamp: 43

2 foot fixtures (u-bends)

2 lamp: 12

\section{Housing Office}

$\underline{\text { West Office }}$

5 2x4 3 lamp recessed fixtures with acrylic lens with T12 CW lamps

$\underline{\text { Conference Room }}$

$62 \times 43$ lamp recessed fixtures with acrylic lens with T12 CW lamps

Hallway

$61 \times 42$ lamp recessed fixtures with acrylic lens with T12 CW lamps 


\section{Directors Office}

$22 \times 44$ lamp recessed fixtures with acrylic lens with T12 CW lamps

$\underline{\text { Office }}$

$12 \times 44$ lamp recessed fixtures with acrylic lens with T12 CW lamps

$\underline{\text { Finance }}$

$12 \times 44$ lamp recessed fixtures with acrylic lens with T12 CW lamps

Kitchen

$12 \times 43$ lamp recessed fixtures with acrylic lens with T12 CW lamps

$\underline{\text { East Offices }}$

$62 \times 43$ lamp recessed fixtures with acrylic lens with T12 CW lamps

Shop

18 6"x4' 2 lamp channel fixtures with open cage screen and F40T12 CW lamps

Laundry

13 2x4 4 lamp surface mounted fixtures with acrylic lens with T12 CW lamps

4 1x4 2 lamp surface mounted fixtures with acrylic lens with T12 CW lamps

2 1x4 2 lamp surface mounted fixtures with acrylic lens with T12 CW lamps (bathroom)

\section{Total}

$\underline{4 \text { foot fixtures }}$

4 lamp: 17

3 lamp: 18

2 lamp: 30

\section{Wildlife \& Parks}

Entry \& Offices

20 2x4 2 lamp surface mounted fixtures with acrylic lens with T12 CW lamps

$\underline{\text { Tool Room }}$

$31 \times 43$ lamp surface mounted C fixtures (open) with T12 CW lamps

$\underline{\text { Shop }}$

4 high bay mercury vapor fixtures (no retrofit; bay door is usually open and shop not used in winter) 


\section{Food Distribution}

Office

4 1x4 2 lamp surface mounted (double check this) fixtures with acrylic lens with T12 CW lamps (best to use new 2 lamp fixtures with T8 841 lamps and electronic ballasts)

Warehouse

17 18”x8' 2 lamp suspended fixtures with C reflector and F96T12CW lamps (single pin)

\section{Human Development Center (HDC)}

Hallway/Foyer

10 18”x4' 4 lamp surface mounted fixtures with acrylic lens with T12 CW lamps

$\underline{\text { Kitchen/Storage }}$

4 18"x4' 4 lamp surface mounted fixtures with acrylic lens with T12 CW lamps

$\underline{\text { Office }}$

118 "x4' 4 lamp surface mounted fixtures with acrylic lens with T12 CW lamps

Meeting

8 18"x4' 4 lamp surface mounted fixtures with acrylic lens with T12 CW lamps

Recreation Office

318 "x4' 4 lamp surface mounted fixtures with acrylic lens with T12 CW lamps

Curriculum Office

3 18"x4' 4 lamp surface mounted fixtures with acrylic lens with T12 CW lamps

$\underline{\text { Economic Development }}$

618 "x4' 4 lamp surface mounted fixtures with acrylic lens with T12 CW lamps

Women's Restroom

318 ' $x$ 4' 4 lamp surface mounted fixtures with acrylic lens with T12 CW lamps

1 18"x4' 2 lamp surface mounted fixture with acrylic lens with T12 CW lamps

Men's Restroom

3 18"x4' 4 lamp surface mounted fixtures with acrylic lens with T12 CW lamps

1 18”x4' 2 lamp surface mounted fixture with acrylic lens with T12 CW lamps 
$\underline{\text { Meeting Room }}$

2318 "x4' 4 lamp surface mounted fixture with acrylic lens with T12 CW lamps

$\underline{\text { Gym }}$

24 metal halide fixtures $(\sim 250 \mathrm{~W})$...no retrofit

$\underline{\text { Weight Room }}$

6 18'x4' 2 lamp surface mounted fixture with acrylic lens with T12 CW lamps (some missing lens)

\section{Total}

4 foot fixtures

4 lamp: 64

2 lamp: 8

\section{Resource Center}

\section{$\underline{\text { Hallway-West End }}$}

9 6"x4' 1 lamp surface mounted fixtures (7 mounted end to end \& 2 mounted separate) w/ old yellow thick plastic lens

(retrofit with new 1 lamp wrap fixture with acrylic lens with T8 841 lamp and electronic ballast)

\section{$\underline{\text { Newspaper }}$}

4 18'x4' 4 lamp surface mounted fixture with acrylic lens with T12 CW lamps (poor condition) (retrofit w/ new 18" x4' 3 lamp surface mounted wrap fixture w/ acrylic lens w/ T8 lamps and electronic ballast)

\section{$\underline{\text { Men's Restroom }}$}

1 4"x4' 2 lamp channel surface mounted fixture with no lens

(retrofit w/ new 2 lamp wrap around surface mounted fixture with acrylic lens ( 6" wide))

\section{$\underline{\text { Women's Restroom }}$}

1 4"x4' 2 lamp channel surface mounted fixture with no lens

(retrofit w/ new 2 lamp wrap around surface mounted fixture with acrylic lens ( 6" wide))

\section{Front Reception Office}

2 18"X4' 4 lamp surface mounted fixture with acrylic lens with T12 CW lamps (poor condition) (retrofit w/ new 18"x4' 3 lamp surface mounted wrap fixture w/ acrylic lens w/ T8 lamps and electronic ballast)

\section{$\underline{\text { South Office }}$}

2 18'x4' 4 lamp surface mounted fixture with acrylic lens with T12 CW lamps (poor condition) (retrofit w/ new 18"x4' 3 lamp surface mounted wrap fixture w/ acrylic lens w/ T8 lamps and electronic ballast)

\section{$\underline{\text { South Office }}$}

4 18'x4' 4 lamp surface mounted fixture with acrylic lens with T12 CW lamps (poor condition) (retrofit w/ new 18"x4' 3 lamp surface mounted wrap fixture w/ acrylic lens w/ T8 lamps and electronic ballast) 


\section{$\underline{\text { SE Office }}$}

4 18"x4' 4 lamp surface mounted fixture with acrylic lens with T12 CW lamps (poor condition)

(retrofit w/ new 18"x4' 3 lamp surface mounted wrap fixture w/ acrylic lens w/ T8 lamps and electronic ballast)

\section{$\underline{\text { Hallway (East End) }}$}

9 6"x4' 1 lamp surface mounted fixtures (7 end to end with 2 separate) with old yellow thick plastic lens (retrofit with new 1 lamp wrap fixture with acrylic lens with T8 841 lamp and electronic ballast)

\section{$\underline{\text { North Offices }}$}

18 2x4 4 lamp surface mounted fixtures with acrylic lens with T12 CW lamps

(older fixtures in OK condition, but may be retrofitted w/ new 3 lamp fixtures to be consistent w/ other new fixtures)

\section{South Offices}

10 2x4 4 lamp surface mounted fixtures with acrylic lens with T12 CW lamps

(older fixtures in OK condition, but may be retrofitted w/ new 3 lamp fixtures to be consistent w/ other new fixtures)

\section{Total}

4 foot fixtures (all new fixtures)

4 lamp: 44

2 lamp: 2

1 lamp: 18

\section{Senior Center/Daycare}

\section{$\underline{\text { Daycare }}$}

26 18'x4' 4 lamp surface mounted fixtures with wrap acrylic lens and T12 Cw lamps (good condition)

$\underline{\text { Hallway }}$

4 6”x4' 2 lamp surface mounted fixtures with acrylic lens with T12 CW lamps

Daycare Coordinators Office

2 18'x4' 4 lamp surface mounted fixtures with wrap acrylic lens and T12 Cw lamps (good condition)

$\underline{\text { Senior Center Offices }}$

4 18’x4' 4 lamp surface mounted fixtures with wrap acrylic lens and T12 Cw lamps (good condition)

$\underline{\text { Kitchen }}$

3 1x4 2 lamp surface mounted fixtures with wraparound acrylic lens with T12 CW lamps

Meeting Room/Offices

14 18'x4' 4 lamp surface mounted fixtures with wrap acrylic lens and T12 Cw lamps (good condition) 


\section{Total}

4 foot fixtures

4 lamp: 46

2 lamp: 7

\section{Owyhee School}

T8 lamps (F032/741) and electronic ballasts are presently used in the hallways of the main school building, not in classrooms or hallways of other school buildings.

Typical 4 foot T12 lamps are F40CWSS; typical 8 foot lamps are F96T12CW 75W (single pin); some 14" T12 lamps are F14T12-D (14 watts); 500W incandescent lamps used in gym.

\section{Main Building}

Hallways/Foyers

No retrofit....2 lamp fixtures (30 in total) already use T8 lamps and electronic ballasts

Computer

18 1x4 2 lamp surface mounted fixtures with acrylic lens with T12 CW lamps (good condition)

$\underline{\text { Home Economics }}$

22 1x4 2 lamp surface mounted fixtures with acrylic lens with T12 CW lamps (good condition)

$\underline{\text { Science }}$

$81 \times 42$ lamp surface mounted fixtures with acrylic lens with T12 CW lamps (good condition)

\section{$\underline{\text { Band Room }}$}

12 metal halide fixtures with $250 \mathrm{~W}$ or $400 \mathrm{~W}$ MH lamps

2 1x4 2 lamp surface mounted fixture with acrylic lens with T12 CW lamps

$\underline{\text { Shop Meeting Room }}$

4 1x4 2 lamp surface mounted fixtures with acrylic lens with T12 CW lamps (good condition)

$\underline{\text { Shop }}$

14 pendant mounted mercury vapor fixtures with $175 \mathrm{~W}$ lamps (no retrofit)

$\underline{\text { Art Room }}$

8 metal halide fixtures with $250 \mathrm{~W}$ or $400 \mathrm{~W}$ MH lamps (no retrofit)

$\underline{\text { SW Offices }}$

7 1x4 2 lamp pendant mounted fixtures with acrylic lens with T12 CW lamps (good condition) 
Mrs Dick Classroom -3

2 1x4 2 lamp pendant mounted fixtures with acrylic lens with T12 CW lamps (good condition) $\underline{\text { Secretary }}$

4 1x4 2 lamp pendant mounted fixtures with acrylic lens with T12 CW lamps (good condition) Mr. Miller Classroom

$81 \times 42$ lamp pendant mounted fixtures with acrylic lens with T12 CW lamps (good condition)

Computer Lab

$81 \times 42$ lamp pendant mounted fixtures with acrylic lens with T12 CW lamps (good condition) Mrs. Olson -8

$81 \times 42$ lamp pendant mounted fixtures with acrylic lens with T12 CW lamps (good condition)

Library

11 1x4 2 lamp pendant mounted fixtures with acrylic lens with T12 CW lamps (good condition)

$\underline{\text { Therapist }}$

$11 \times 42$ lamp surface mounted fixture with acrylic lens with T12 CW lamps

5 surface mounted round incandescent fixtures with 2 bulbs

Mrs. Holmes -10

$81 \times 42$ lamp pendant mounted fixtures with acrylic lens with T12 CW lamps (good condition) Ms. Rhoden -12

$81 \times 42$ lamp pendant mounted fixtures with acrylic lens with T12 CW lamps (good condition) $\underline{\text { Staff Room }}$

4 1x4 2 lamp pendant mounted fixtures with acrylic lens with T12 CW lamps (good condition) $\underline{\text { Dean }}$

2 1x4 2 lamp surface mounted fixtures with acrylic lens with T12 CW lamps (good condition) $\underline{\text { Custodian/Stairs }}$

$11 \times 42$ lamp surface mounted fixtures with acrylic lens with T12 CW lamps (good condition) 2 surface mounted round incandescent fixtures with 2 bulbs

Ms. Labesky -19

$81 \times 42$ lamp pendant mounted fixtures with acrylic lens with T12 CW lamps (good condition) 


\section{Boys Restroom}

2 surface mounted round incandescent fixtures with 2 bulbs

Girls Restroom

2 surface mounted round incandescent fixtures with 2 bulbs

Computer Lab -18

8 1x4 2 lamp pendant mounted fixtures with acrylic lens with T12 CW lamps (good condition)

Mrs. Lewis -13

$81 \times 42$ lamp pendant mounted fixtures with acrylic lens with T12 CW lamps (good condition)

Mrs. Woods -14

6 1x4 2 lamp pendant mounted fixtures with acrylic lens with T12 CW lamps (good condition)

Mrs. Bieroth -17

8 1x4 2 lamp pendant mounted fixtures with acrylic lens with T12 CW lamps (good condition)

Mrs. Thomas -15

$81 \times 42$ lamp pendant mounted fixtures with acrylic lens with T12 CW lamps (good condition)

Ms. Manning -16

$81 \times 42$ lamp pendant mounted fixtures with acrylic lens with T12 CW lamps (good condition)

Gym

North Foyer and Hallway

13 2x4 2 lamp fixtures with acrylic lens and T12 CW lamps

$\underline{\text { Kitchen }}$

8 6"x8' 2 lamp fixtures with clear lens and T12 CW lamps

2 6"x4' 2 lamp fixtures with clear lens and T12 CW lamps

Gym

64 high wattage $(500 \mathrm{~W})$ incandescent fixtures

(retrofit with $250 \mathrm{~W}$ high bay metal halide fixtures....proper count and spacing must be analyzed)

Boys Locker

16 6"x4' 2 lamp fixtures with clear lens with T12 CW lamps

2 6"x4' 1 lamp fixtures with no lens with T12 CW lamps 
Girls Locker

12 6"x4' 2 lamp fixtures with clear lens with T12 CW lamps

$\underline{\text { Boys Restroom }}$

$11 \times 42$ lamp wall mount fixture with T12 CW lamps

2 1x4 2 lamp surface mount (with lens missing)

$11 \times 32$ lamp fixture with T12 CW lamps

Girls Restroom

$11 \times 42$ lamp wall mount fixture with T12 CW lamps

2 1x4 2 lamp surface mount (with lens missing)

1 1x3 2 lamp fixture with T12 CW lamps

$\underline{\text { Gym Classroom }}$

48 (8 rows of 6) 1x4 2 lamp pendant mounted fixtures w/ acrylic lens with T12 CW lamps (many fixtures missing lens)

\section{Vo-Tech Building}

Boys Restroom

1 6"x4' 2 lamp surface mounted fixture with acrylic lens with T12 CW lamps

16 "x4' 2 lamp wall mounted fixture (above mirror) with acrylic lens with T12 CW lamps

Girls Restroom

16 "x4' 2 lamp surface mounted fixture with acrylic lens with T12 CW lamps

1 6"x4" 2 lamp wall mounted fixture (above mirror) with acrylic lens with T12 CW lamps

Classroom

15 2x4 4 lamp surface mounted fixtures with acrylic lens with T12 CW lamps (good condition)

(room is very bright... 105 footcandles... retrofit with 4 lamp ballasts but delamp to 2 or 3 lamps)

Auto Shop

28 metal halide fixtures with 250W MH lamps (no retrofit)

Hallway

$31 \times 42$ lamp surface mounted fixtures with acrylic lens with T12 CW lamps

\section{Other School Buildings}

Garage-Bus Bay 
11 metal halide fixtures with 250W MH lamps (no retrofit)

Modular-Southwest

28 6"x4' 2 lamp surface mounted fixtures with acrylic lens with T12 CW lamps

Modular Building (North)

28 6"x4' 2 lamp surface mounted fixtures with acrylic lens with T12 CW lamps

\section{Total}

4 foot fixtures

4 lamp: 15

2 lamp: 350

1 lamp: 2

\section{Owyhee Café}

15 2x4 4 lamp surface mounted fixtures with T12 lamps (some fixtures not working, some w/ no lens)

(retrofit w/ new 2x4 3 lamp surface mounted fixtures w/ wraparound lens w/ T8 841 lamps and electronic ballasts)

\section{Other Major Buildings}

Juvenile Center - New building with efficient lighting

Fire Station - New building with efficient lighting

Prison - BIA facility; high security and advance permission was not obtained for audit period

Tribal Court - Older, smaller building with real hodge podge of lighting fixtures...low priority 


\section{SUMMARY RESULTS OF LIGHTING AUDITS FOR MAJOR BUILDINGS ON DUCK VALLEY RESERVATION}

Owyhee Hospital

Fixture Fixture Fixture Annual Annual Fixture Annual

Power Energy

Annual Annual

Cost of Retrofit

Program Utility

Net

Simple

$\begin{array}{lllll}\text { (W) } & \mathbf{( k W h )} & \mathbf{( \$ )} & \mathbf{( W )} & \mathbf{( k W h )} \\ 192 & 197345.3 & 11841 & 98 & 100728.3\end{array}$

Savings

(\$)

(\$)

Tota

Rebate

Cost

Payback

4' 4 lamp

4' 2 lamp

8 ' 2 lamp

969194

$96 \quad 91944.96$

5517

$\begin{array}{ll}51 & 48845.76\end{array}$

$158 \quad 7381.76$

443

$110 \quad 5139.2$

4' 3 lamp

U 2 lamp

9642608.64

1716

$75 \quad 14892$

$51 \quad 22635.84$

$6044 \quad 5797 \quad 2992$

$2931 \quad 2586 \quad 2296$

308

135

$822 \quad 544$

$1584 \quad 4576$

0

(\$) (\$)

(Yr)

894
1358

1198
10538

1064

$738 \quad 3034$

$\begin{array}{rr}112 & 312 \\ 229.5 & 774\end{array}$

$912 \quad 1976$

10671.5

\section{Tribal Headquarters}

Type Count

4' 4 lamp
4' 2 lamp
U 2 lamp
60-75W Incan

Fixture Anr

Power Energy Cost Power Energy

Annual Annual

Cost of Retrofit

Program Utility

3034

312

774

1976

10671.5

(W) (kWh) (\$)

(\$)

(\$)

Ballast Lamps

Total Rebat

bebate

Net

Simple

$\begin{array}{lllll}192 & 49896.96 & 2994 & 98 & 25468.24\end{array}$

$96 \quad 12053.76$

$96 \quad 3363.84$

723

202

$51 \quad 6403.56$

$51 \quad 1787.04$

$1528 \quad 1466$

(\$)

(\$)

(\$)

(\$)

(\$)

(\$)

Payback

$\begin{array}{rrrrr}384 & 339 & 602 & 193.5 & 796 \\ 107 & 95 & 192 & 144 & 336\end{array}$

$107 \quad 95$

192

$\begin{array}{rr}237 & 749 \\ & 1899\end{array}$

$375 \quad 375$

0

2314

336

3821

\section{Housing Office}

Fixture

Type Count

Power

Annual

Annual

$\begin{array}{llll}\text { (W) } & \text { (kWh) } & \text { (\$) } & \text { (W) }\end{array}$

Annual

Annual Annual

Cost Savings

Ballast

Program Utility

3820.5

2.3

3.6

0.5

2.0

4' 4 lamp

4' 2 lamp

$\begin{array}{ll}\text { A } & 17\end{array}$

$192 \quad 9530.88$

(\$) 572

(W) (kWh)

(\$)

(\$)

(\$)

(\$)

Tota
(\$)

(\$)

Rebate

Net

Simple

$\begin{array}{ll}292 & 280 \\ 268 & 237\end{array}$

289

420

153

442

0

(\$)

(\$)

Payback

$\begin{array}{lllll}96 & 8409.6 & 505 & 51 & 4467.6\end{array}$

237

218
734

288

$135-555$

410
1406.5

0

0
0

442

555

1.6

2.3

Whe

Wildlife \& Parks

Type Count Power

Annual

Annual Fixture Annual

Energy Cost Power Energy

Annual Annual

Cost of Retrofit

Program Utility

1406.5

$\begin{array}{llll}\text { (W) } & (\mathrm{kWh}) & \text { (\$) } & \text { (W) }\end{array}$

(\$)

(\$)

Ballast

Lamp

Total

Rebate Rebate

Net

Simple

4' 2 lamp

1441261.

336
76

$\begin{array}{ll}51 & 2978.4 \\ 75 & \end{array}$

179

$158 \quad 280$

90

(\$)

(\$)

(\$)

Payback

4' 3 lamp

D

194
370
20.25
280
48

$\begin{array}{rr}20.25 & 68 \\ & 438.25\end{array}$

0
0
0

$\begin{array}{rr}0 & 68 \\ 0 & 438.25\end{array}$




\section{Food Distribution}

\begin{tabular}{|c|c|c|c|c|c|c|c|c|c|c|c|c|c|c|c|}
\hline Fixture & Fixture & Fixture & Annual & Annual & Fixture & Annual & Annual & Annual & Co & t of Retrof & & Program & Utility & Net & Simple \\
\hline Type & Count & $\begin{array}{l}\text { Power } \\
\text { (W) }\end{array}$ & $\begin{array}{c}\text { Energy } \\
\text { (kWh) }\end{array}$ & $\begin{array}{c}\text { Cost } \\
\text { (\$) }\end{array}$ & $\begin{array}{c}\text { Power } \\
\text { (W) }\end{array}$ & $\begin{array}{c}\text { Energy } \\
\text { (kWh) }\end{array}$ & $\begin{array}{c}\text { Cost } \\
\text { (\$) }\end{array}$ & $\begin{array}{l}\text { Savings } \\
\text { (\$) }\end{array}$ & $\begin{array}{c}\text { Ballast } \\
(\$)\end{array}$ & $\begin{array}{l}\text { Lamps } \\
\text { (\$) }\end{array}$ & $\begin{array}{c}\text { Total } \\
\text { (\$) }\end{array}$ & $\begin{array}{c}\text { Rebate } \\
\text { (\$) }\end{array}$ & $\begin{array}{c}\text { Rebate } \\
\text { (\$) }\end{array}$ & $\begin{array}{c}\text { Cost } \\
\text { (\$) }\end{array}$ & $\begin{array}{c}\text { Payback } \\
\text { (Yr) }\end{array}$ \\
\hline B & 4 & 96 & 1121.28 & 67 & 51 & 595.68 & 36 & 32 & 56 & 18 & 74 & 0 & 0 & 74 & 2.3 \\
\hline C & 17 & 158 & 7843.12 & 471 & 110 & 5460.4 & 328 & 143 & 425 & 238 & 663 & 0 & 0 & 663 & 4.6 \\
\hline & & & & & & & & 174 & & & 737 & 0 & 0 & 737 & 4.2 \\
\hline
\end{tabular}

\section{Human Development Center}

\begin{tabular}{|c|c|c|c|c|c|c|c|c|c|c|c|c|c|c|c|}
\hline ixture & Fixture & Fixture & Annual & Annual & Fixture & Annual & Annual & Annual & \multicolumn{3}{|c|}{ Cost of Retrofit } & Program & Utility & Net & Simple \\
\hline Type & Count & $\begin{array}{l}\text { Power } \\
\text { (W) }\end{array}$ & $\begin{array}{c}\text { Energy } \\
\text { (kWh) }\end{array}$ & $\begin{array}{c}\text { Cost } \\
\text { (\$) }\end{array}$ & $\begin{array}{c}\text { Power } \\
\text { (W) }\end{array}$ & $\begin{array}{c}\text { Energy } \\
\text { (kWh) }\end{array}$ & $\begin{array}{c}\text { Cost } \\
(\$)\end{array}$ & $\begin{array}{c}\text { Savings } \\
(\$)\end{array}$ & $\begin{array}{c}\text { Ballast } \\
\text { (\$) }\end{array}$ & $\begin{array}{l}\text { Lamps } \\
\text { (\$) }\end{array}$ & $\begin{array}{c}\text { Total } \\
(\$)\end{array}$ & $\begin{array}{c}\text { Rebate } \\
\text { (\$) }\end{array}$ & $\begin{array}{c}\text { Rebate } \\
\text { (\$) }\end{array}$ & $\begin{array}{c}\text { Cost } \\
(\$)\end{array}$ & $\begin{array}{c}\text { Payback } \\
\text { (Yr) }\end{array}$ \\
\hline A & 64 & 192 & 35880.96 & 2153 & 98 & 18314.24 & 1099 & 1054 & 1088 & 576 & 1664 & 0 & 0 & 1664 & 1.6 \\
\hline B & 8 & 96 & 2242.56 & 135 & 51 & 1191.36 & 71 & 63 & 112 & 36 & 148 & 0 & 0 & 148 & 2.3 \\
\hline & & & & & & & & 1117 & & & 1812 & 0 & 0 & 1812 & 1. \\
\hline
\end{tabular}

\section{Resource Center}

Fixture Fixture Fixture Annual Annual Fixture Annual

Type Count Power Energy Cost Power Energy

\section{Annual Annual}

Program Utility

Net Simple

(\$) Savings

Ballast Lamps Total

Rebate Rebate

Cost

Payback

$\begin{array}{lllll}(\mathrm{W}) & (\mathrm{kWh}) & \text { (\$) } & \text { (W) } & \text { (kWh) }\end{array}$

$\begin{array}{lrrrrrrr}\text { 4' } 4 \text { lamp } & \mathrm{A} & 44 & 192 & 24668.16 & 1480 & 98 & 12591.04 \\ \text { 4' } 2 \text { lamp } & \mathrm{B} & 2 & 96 & 560.64 & 34 & 51 & 297.84\end{array}$

4' 1 lamp

G

755

(\$) (\$)

725 New

$16 \mathrm{New}$

$69 \mathrm{New}$

810

$\begin{array}{ll}\text { New } & \text { New } \\ \text { New } & \text { New } \\ \text { New } & \text { New }\end{array}$

NA
(\$)

(\$)

(\$)

NA

NA

NA

NA

\section{Senior Center/Daycare}

Type Count

4' 4 lamp

A

4' 2 lamp

\begin{tabular}{|c|c|c|c|c|}
\hline ture & Annual & Annual & Fixture & Annual \\
\hline $\begin{array}{l}\text { ower } \\
\text { (W) }\end{array}$ & $\begin{array}{l}\text { Energy } \\
\text { (kWh) }\end{array}$ & $\begin{array}{c}\text { Cost } \\
\text { (\$) }\end{array}$ & $\begin{array}{l}\text { Power } \\
\text { (W) }\end{array}$ & $\begin{array}{l}\text { Energy } \\
\text { (kWh) }\end{array}$ \\
\hline 192 & 25789.44 & 1547 & 98 & 13163.36 \\
\hline 96 & 1962.24 & 118 & 51 & 1042.44 \\
\hline
\end{tabular}

Annual Annual

Program Utilit

(\$) (\$)

(\$)

Ballast

(\$)

Lamps

(\$)

(\$)
1196

(\$) 0

$$
31 .
$$

813

Annual Annual

Cost of Retrofit

130
1325.5

0

(\$)

Net

Cost

Simple

Payback

(Yr)

1.6

2.3
1.6

\section{Owyhee School}

$\begin{array}{ccc}\text { Fixture } & \text { Fixture } & \text { Fixture } \\ \text { Type } & \text { Count } & \text { Power }\end{array}$

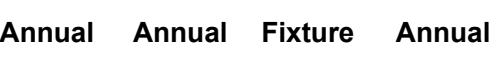

\begin{tabular}{llrrr} 
(W) & (kWh) & \multicolumn{1}{l}{$(\mathbf{\$})$} & \multicolumn{1}{l}{ (W) } & \multicolumn{1}{l}{ (kWh) } \\
192 & 8409.6 & 505 & 98 & 4292.4
\end{tabular}

4' 4 lamp

4' 2 lamp

15
350

$\begin{array}{rrr}192 & 8409.6 & 505 \\ 96 & 98112 & 5887\end{array}$

$\begin{array}{rr}98 & 4292.4 \\ 51 & 52122\end{array}$

(\$) 258

(\$)

255

(\$)

(\$)

(\$)

(\$)

(\$)

Payback

3127

4900
28

$\begin{array}{rr}135 & 390 \\ 1575 & 6475\end{array}$
2759

3014

0
0
0
0

$\begin{array}{lr}0 & 390 \\ 0 & 6475 \\ 0 & 33 \\ 0 & 6897.5\end{array}$


Owyhee Café

\begin{tabular}{|c|c|c|c|c|c|c|c|c|c|c|c|c|c|c|c|}
\hline ture & ure & Fixture & Annual & Annual & Fixture & Annual & Annual & Annual & & st of Retr & & Program & Jtility & Net & Simple \\
\hline pe & Count & $\begin{array}{l}\text { Power } \\
\text { (W) }\end{array}$ & $\begin{array}{l}\text { Energy } \\
\text { (kWh) }\end{array}$ & $\begin{array}{l}\text { Cost } \\
\text { (\$) }\end{array}$ & $\begin{array}{l}\text { Power } \\
\text { (W) }\end{array}$ & $\begin{array}{l}\text { Energy } \\
\text { (kWh) }\end{array}$ & $\begin{array}{c}\text { Cost } \\
(\$)\end{array}$ & $\begin{array}{c}\text { Savings } \\
\text { (\$) }\end{array}$ & $\begin{array}{c}\text { Ballast } \\
\text { (\$) }\end{array}$ & $\begin{array}{c}\text { Lamps } \\
\text { (\$) }\end{array}$ & $\begin{array}{c}\text { Total } \\
(\$)\end{array}$ & $\begin{array}{c}\text { Rebate } \\
\text { (\$) }\end{array}$ & $\begin{array}{c}\text { Rebate } \\
\text { (\$) }\end{array}$ & $\begin{array}{c}\text { Cost } \\
\text { (\$) }\end{array}$ & $\begin{array}{c}\text { Payback } \\
\text { (Yr) }\end{array}$ \\
\hline A & 15 & 192 & 10512 & 631 & 98 & 5365.5 & 322 & 309 & New & New & New & 0 & $c$ & NA & \\
\hline
\end{tabular}

Annual Operating Cost Savings: All Buildings (except Resource Center and Owyhee Café w/ New Fixtures)

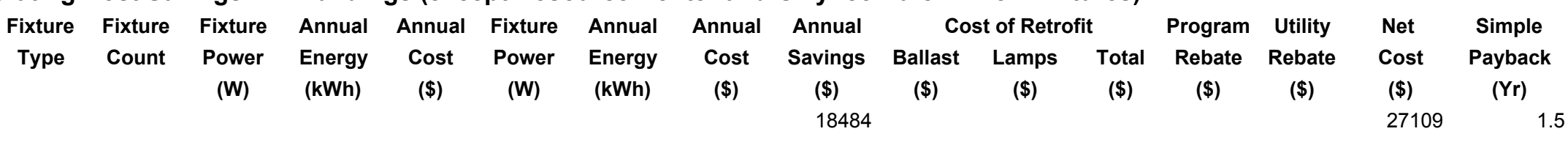

Electric Demand Reduction: All Buildings (except Resource Center and Owyhee Café w/ New Fixtures)

\begin{tabular}{|c|c|c|c|c|c|c|c|c|c|c|c|c|c|c|c|}
\hline \multirow{3}{*}{$\begin{array}{l}\text { Fixture } \\
\text { Type }\end{array}$} & \multirow{2}{*}{$\begin{array}{c}\text { Fixture } \\
\text { Count }\end{array}$} & \multirow{2}{*}{$\begin{array}{c}\text { Existing } \\
\text { Power } \\
\text { (W) }\end{array}$} & \multirow{2}{*}{$\begin{array}{c}\text { Annual } \\
\text { Energy } \\
\text { (kWh) }\end{array}$} & \multirow{2}{*}{$\begin{array}{c}\text { Annual } \\
\text { Cost } \\
(\$)\end{array}$} & \multirow{2}{*}{$\begin{array}{l}\text { Retrofit } \\
\text { Power } \\
\text { (W) }\end{array}$} & \multirow{2}{*}{$\begin{array}{c}\text { Annual } \\
\text { Energy } \\
\text { (kWh) }\end{array}$} & \multirow{2}{*}{$\begin{array}{c}\text { Annual } \\
\text { Cost } \\
(\$)\end{array}$} & \multirow{2}{*}{$\begin{array}{l}\text { Demand } \\
\text { Reduction } \\
\text { (kW) }\end{array}$} & \multicolumn{3}{|c|}{ Cost of Retrofit } & \multirow{2}{*}{$\begin{array}{c}\text { Program } \\
\text { Rebate } \\
\text { (\$) }\end{array}$} & \multirow{2}{*}{$\begin{array}{c}\text { Utility } \\
\text { Rebate } \\
\text { (\$) }\end{array}$} & \multirow{2}{*}{$\begin{array}{c}\text { Net } \\
\text { Cost } \\
(\$)\end{array}$} & \multirow{2}{*}{$\begin{array}{c}\text { Simple } \\
\text { Payback } \\
\text { (Yr) }\end{array}$} \\
\hline & & & & & & & & & $\begin{array}{c}\text { Ballast } \\
\text { (\$) }\end{array}$ & $\begin{array}{c}\text { Lamps } \\
\text { (\$) }\end{array}$ & $\begin{array}{c}\text { Total } \\
\text { (\$) }\end{array}$ & & & & \\
\hline & & 164283 & & & 90081 & & & 74.202 & & & & & & & \\
\hline
\end{tabular}

\section{Existing Fixture Types}

Fixture Type A: 4 foot 4 lamp fluorescent fixture, magnetic ballast, and 4 foot T12 lamps

Fixture Type B: 4 foot 2 lamp fluorescent fixture with $2 \mathrm{~T} 12$ lamps and magnetic ballast

Fixture Type C: 8 foot 2 lamp fluorescent fixture w/ mag. ballast \& F96T12CW 60W lamps

Fixture Type D: 4 foot 3 lamp fluorescent fixture, magnetic ballast, and 4 foot T12 lamps

Fixture Type E: $\quad 2 \times 22$ lamp U-bend fluorescent fixture, magnetic ballast, and U-bend lamps

Fixture Type F: $\quad 60-75 \mathrm{~W}$ incandescent fixture

Fixture Type G: 4 foot 1 lamp fluorescent fixture w/ magnetic ballast

Assumptions:

\section{Retrofit Recommendation}

Use a 4 lamp electronic ballast w/ 4 T8 lamps (Sylvania QT4x32LP ballast and F032/841/XP/ECO lamps) - Delamp as necessary Use a 3 lamp electronic ballast w/ 3 T8 lamps (Sylvania QT3×32LP ballast and F032/841/XP/ECO lamps) - Delamp as necessary Use 2 F096/841/XP/ECO lamps and 1 QT2x59IS electronic ballast

Use a 3 lamp electronic ballast w/ 3 T8 lamps (Sylvania QT3×32LP ballast and F032/841/XP/ECO lamps) - Delamp as necessary Use 2 F032U/841/XP/ECO U-bend lamps and 1 QT2×32LP electronic ballas

Use screw-in compact fluorescent lamp (CFL) 18W

Use a 1 lamp electronic ballast w/ 1 T8 lamp (QT1×32T8IS ballast and F032/841/XP/ECO lamp)

1) Electric Rate: $\$ 0.06 / \mathrm{kWh}$

2) No labor costs are included in retrofit cost totals; electrician/technician labor is assumed to be conducted by current facility maintenance staff

3) Hours of Operation:

Owyhee Hospital: 16 average hours per day per fixture (some are lit 8-10 hours, others lit 24 hours)

Tribal Headquarters: 8 average hours per day

Housing Office: 8 average hours per day

Wildlife \& Parks: 8 average hours per day

Food Distribution: 8 average hours per day

Human Development Center: 8 average hours per day

Resource Center: 8 average hours per day

Senior Center/Daycare: 8 average hour per day

Owyhee School: 8 average hours per day (during school year hours are higher; during summer hours are lower)

Owyhee Café: 10 average hours per day 


\section{APPENDIX B \\ WIND ANALYSIS SUMMARY REPORTS \\ (MILLER CREEK SITE)}

On the following pages:

INEEL Wind Resource Report

Wind Farm Electrical Output and Financial Modeling Results

0.14 Shear Scenario

Modeling Worksheet

Equipment Worksheet

Cost Worksheet

Financial Worksheet

0.20 Shear Scenario

Modeling Worksheet

Equipment Worksheet

Cost Worksheet

Financial Worksheet

0.26 Shear Scenario

Modeling Worksheet

Equipment Worksheet

Cost Worksheet

Financial Worksheet 
INEEL Wind Resource Report

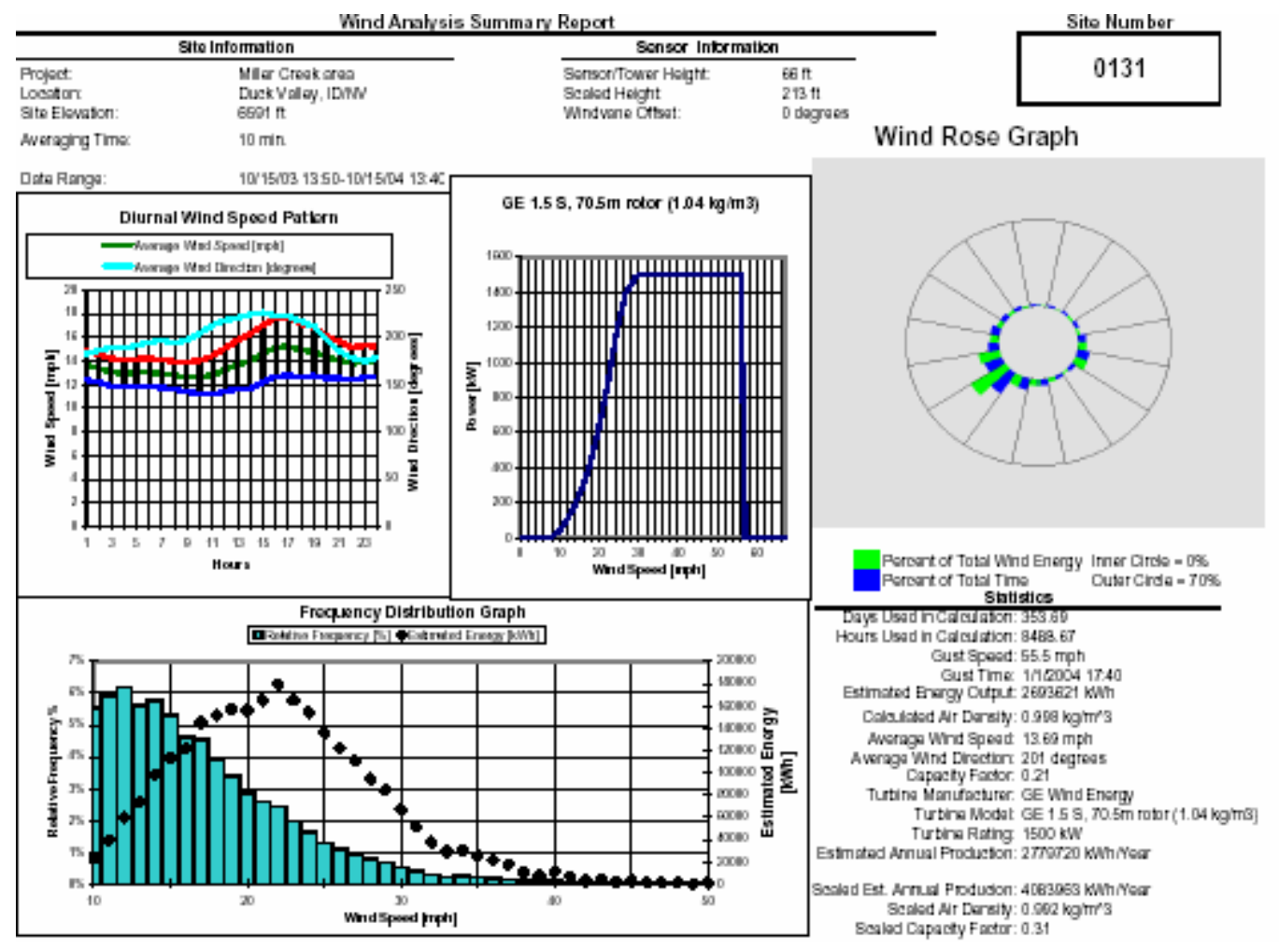




\section{RETScreen ${ }^{\circledR}$ Energy Model - Wind Energy Project}

\section{Site Conditions}

Project name

Project location

Nearest location for weather data

Annual average wind speed

Height of wind measurement

Wind shear exponent

Wind speed at $10 \mathrm{~m}$

Average atmospheric pressure

Annual average temperature
Estimate

Notes/Range

\begin{tabular}{c|c|}
\multirow{4}{*}{} & 0.14 Shear \\
\cline { 2 - 2 } & Duck Valley \\
\cline { 2 - 2 } $\mathrm{m} / \mathrm{s}$ & Miller Creek \\
\cline { 2 - 2 } $\mathrm{m}$ & 6.2 \\
\cline { 2 - 2 }- & 20.0 \\
\cline { 2 - 2 } $\mathrm{m} / \mathrm{s}$ & 0.14 \\
$\mathrm{kPa}$ & 5.6 \\
\cline { 2 - 2 }${ }^{\circ} \mathrm{C}$ & 91.6 \\
\hline
\end{tabular}

See Weather Database

3.0 to 100.0

0.10 to 0.25

60.0 to 103.0 -20 to 30

System Characteristics

Grid type

Wind turbine rated power

Number of turbines

Wind plant capacity

Hub height

Wind speed at hub height

Array losses

Airfoil soiling and/or icing losses

Other downtime losses

Miscellaneous losses

\begin{tabular}{c|c}
\multicolumn{1}{c}{} & \multicolumn{1}{c}{ Estimate } \\
\hline kW & Central-grid \\
\cline { 2 - 2 }- & 1,650 \\
\cline { 2 - 2 } $\mathrm{kW}$ & 30 \\
$\mathrm{n}$ & 49,500 \\
$\mathrm{~m} / \mathrm{s}$ & 67.0 \\
$\%$ & 7.3 \\
$\%$ & $3 \%$ \\
$\%$ & $2 \%$ \\
\cline { 2 - 2 }$\%$ & $2 \%$ \\
\cline { 2 - 2 }$\%$ & $3 \%$ \\
\hline
\end{tabular}

Notes/Range

Complete Equipment Data sheet

6.0 to 100.0

3.0 to 15.0

$0 \%$ to $20 \%$

$1 \%$ to $10 \%$

$2 \%$ to $7 \%$

$2 \%$ to $6 \%$

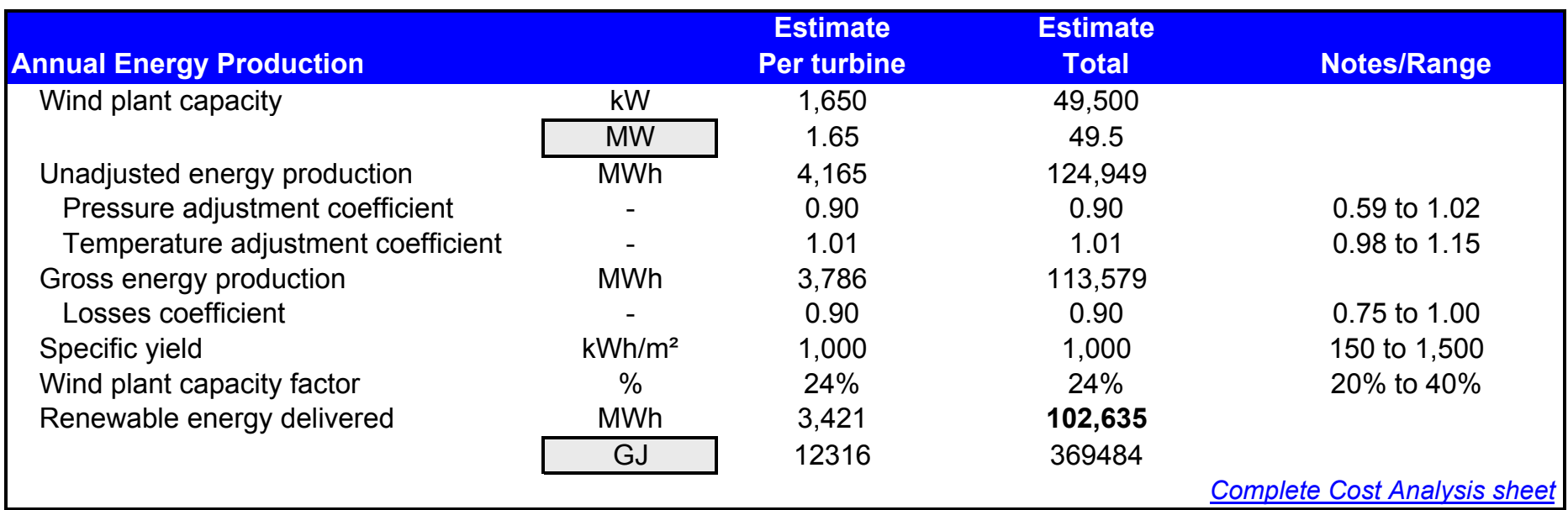

NRCan/CEDRL 
Wind Turbine Characteristics

Wind turbine rated power

Hub height

Rotor diameter

Swept area

Wind turbine manufacturer

Wind turbine model

Energy curve data source

Shape factor
Estimate

\begin{tabular}{c|c|}
\multirow{3}{*}{$\mathrm{kW}$} & 1,650 \\
\cline { 2 - 2 } $\mathrm{m}$ & 67.0 \\
\cline { 2 - 2 } $\mathrm{m}^{2}$ & 66 \\
\cline { 2 - 2 } & 3,421 \\
\cline { 2 - 2 } & Vestas Wind Systems \\
\cline { 2 - 2 } & VESTAS V66-1.65MW \\
\cline { 2 - 2 }- & Custom \\
\cline { 2 - 2 }- & 2.1 \\
\hline
\end{tabular}

Notes/Range

See Product Database

6.0 to 100.0

7 to 72

35 to 4,075

Weibull wind distribution 1.0 to 3.0

\section{Wind Turbine Production Data}

Wind speed $\quad$ Power curve data

$(\mathrm{m} / \mathrm{s})$

(kW)

Energy curve data

\begin{tabular}{|c|c|c|}
\hline$(\mathrm{m} / \mathrm{s})$ & $(\mathrm{kW})$ & (MWh/yr) \\
\hline 0 & 0.0 & - \\
\hline 1 & 0.0 & - \\
\hline 2 & 0.0 & - \\
\hline 3 & 0.0 & 214.7 \\
\hline 4 & 13.5 & 716.6 \\
\hline 5 & 80.8 & $1,533.1$ \\
\hline 6 & 169.0 & $2,588.2$ \\
\hline 7 & 289.0 & $3,761.0$ \\
\hline 8 & 448.0 & $4,937.4$ \\
\hline 9 & 644.0 & $6,033.7$ \\
\hline 10 & 858.0 & $6,992.3$ \\
\hline 11 & $1,069.0$ & $7,775.8$ \\
\hline 12 & $1,263.0$ & $8,366.1$ \\
\hline 13 & $1,431.0$ & $8,764.1$ \\
\hline 14 & $1,552.0$ & $8,985.6$ \\
\hline 15 & $1,617.0$ & $9,055.3$ \\
\hline 16 & $1,642.0$ & - \\
\hline 17 & $1,649.0$ & - \\
\hline 18 & $1,650.0$ & - \\
\hline 19 & $1,650.0$ & - \\
\hline 20 & $1,650.0$ & - \\
\hline 21 & $1,650.0$ & - \\
\hline 22 & $1,650.0$ & - \\
\hline 23 & $1,650.0$ & - \\
\hline 24 & $1,650.0$ & - \\
\hline 25 & $1,650.0$ & - \\
\hline
\end{tabular}

Power and Energy Curves

$\multimap$ Power $\longrightarrow$ Energy

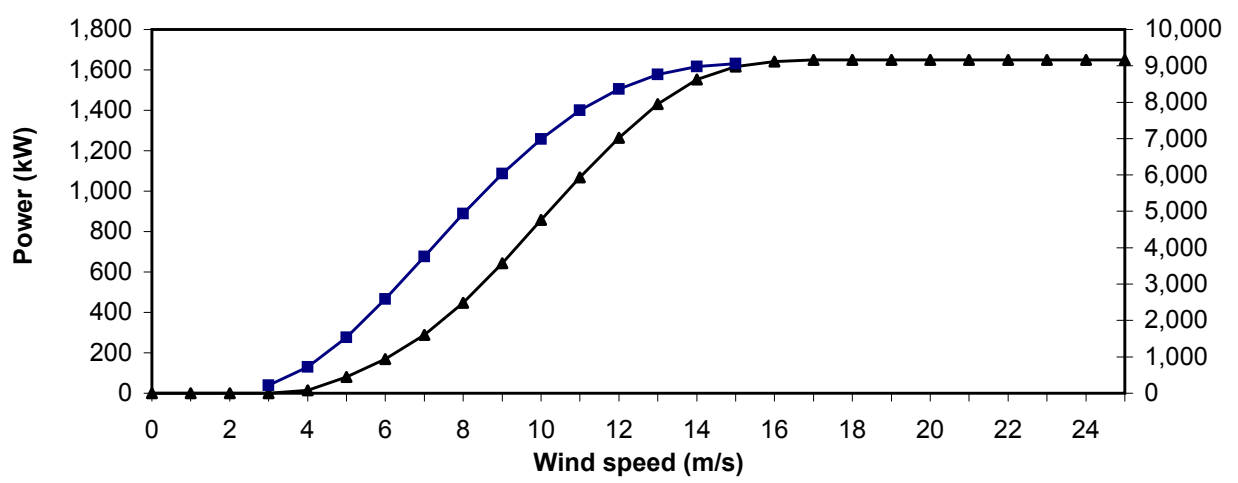

Return to

Energy Model sheet 


$$
\text { Type of project: Custom }
$$

Currency:

$\$$

Cost references:

\begin{tabular}{|c|c|c|c|c|c|c|c|c|c|}
\hline Initial Costs (Credits) & Unit & Quantity & & Unit Cost & & Amount & Relative Costs & Quantity Range & Unit Cost Range \\
\hline Feasibility Study & & & & & & & & & \\
\hline Site investigation & $p-d$ & 6 & $\$$ & 800 & $\$$ & 4,800 & & - & - \\
\hline Wind resource assessment & met tower & 2 & $\$$ & 40,000 & $\$$ & 80,000 & & - & - \\
\hline Environmental assessment & $p-d$ & 24 & $\$$ & 800 & $\$$ & 19,200 & & - & - \\
\hline Preliminary design & $p-d$ & 48 & $\$$ & 800 & $\$$ & 38,400 & & - & - \\
\hline Detailed cost estimate & $p-d$ & 18 & $\$$ & 800 & $\$$ & 14,400 & & - & - \\
\hline Report preparation & p-d & 16 & $\$$ & 800 & $\$$ & 12,800 & & - & - \\
\hline Project management & $p-d$ & 16 & $\$$ & 800 & $\$$ & 12,800 & & - & - \\
\hline Travel and accommodation & p-trip & 8 & $\$$ & 2,000 & $\$$ & 16,000 & & - & - \\
\hline Other & Cost & 0 & $\$$ & - & $\$$ & - & & - & - \\
\hline Sub-total: & & & & & $\$$ & 198,400 & $0.4 \%$ & & \\
\hline Development & & & & & & & & & \\
\hline PPA negotiation & $p-d$ & 20 & $\$$ & 1,200 & $\$$ & 24,000 & & - & - \\
\hline Permits and approvals & $\mathrm{p}-\mathrm{d}$ & 100 & $\$$ & 800 & $\$$ & 80,000 & & - & - \\
\hline Land rights & project & 0 & $\$$ & 30,000 & $\$$ & - & & - & - \\
\hline Land survey & $p-d$ & 20 & $\$$ & 600 & $\$$ & 12,000 & & - & - \\
\hline Project financing & $p-d$ & 50 & $\$$ & 1,500 & $\$$ & 75,000 & & - & - \\
\hline Legal and accounting & $p-d$ & 50 & $\$$ & 1,200 & $\$$ & 60,000 & & - & - \\
\hline Project management & $\mathrm{p}-\mathrm{yr}$ & 1.25 & $\$$ & 130,000 & $\$$ & 162,500 & & - & - \\
\hline Travel and accommodation & p-trip & 18 & $\$$ & 2,000 & $\$$ & 36,000 & & - & - \\
\hline Other & Cost & 0 & $\$$ & - & $\$$ & - & & - & - \\
\hline Sub-total: & & & & & $\$$ & 4449,500 & $101.0 \%$ & & \\
\hline Engineering & & & & & & & & & \\
\hline Wind turbine(s) micro-siting & $p-d$ & 100 & $\$$ & 800 & $\$$ & 80,000 & & - & - \\
\hline Mechanical design & $p-d$ & 50 & $\$$ & 800 & $\$$ & 40,000 & & - & - \\
\hline Electrical design & $p-d$ & 100 & $\$$ & 800 & $\$$ & 80,000 & & - & - \\
\hline Civil design & $\mathrm{p}-\mathrm{d}$ & 90 & $\$$ & 800 & $\$$ & 72,000 & & - & - \\
\hline Tenders and contracting & $\mathrm{p}-\mathrm{d}$ & 80 & $\$$ & 800 & $\$$ & 64,000 & & - & - \\
\hline Construction supervision & $\mathrm{p}-\mathrm{yr}$ & 0.85 & $\$$ & 130,000 & $\$$ & 110,500 & & - & - \\
\hline Other & Cost & 0 & $\$$ & - & $\$$ & - & & - & - \\
\hline Sub-total: & & & & & $\$$ & $\overline{446,500}$ & $0.9 \%$ & & \\
\hline Renewable Energy (RE) Equipment & & & & & & & & & \\
\hline Wind turbine(s) & $\mathrm{kW}$ & 49,500 & $\$$ & 600 & $\$$ & $29,700,000$ & & - & - \\
\hline Spare parts & $\%$ & $2.0 \%$ & $\$$ & $29,700,000$ & $\$$ & 594,000 & & - & - \\
\hline Transportation & turbine & 30 & $\$$ & 10,000 & $\$$ & 300,000 & & - & - \\
\hline Other & Cost & 49,500 & $\$$ & 100 & $\$$ & $4,950,000$ & & - & - \\
\hline Sub-total: & & & & & $\$$ & $35,544,000$ & $\overline{75.1 \%}$ & & \\
\hline Balance of Plant & & & & & & & & & \\
\hline Wind turbine(s) foundation(s) & turbine & 30 & $\$$ & 78,000 & $\$$ & $2,340,000$ & & - & - \\
\hline Wind turbine(s) erection & turbine & 30 & $\$$ & 52,000 & $\$$ & $1,560,000$ & & - & - \\
\hline Road construction & $\mathrm{km}$ & 10.00 & $\$$ & 50,000 & $\$$ & 500,000 & & - & - \\
\hline Transmission line and substation & project & 1 & $\$$ & $1,500,000$ & $\$$ & $1,500,000$ & & - & - \\
\hline Control and O\&M building(s) & building & 1 & $\$$ & 125,000 & $\$$ & 125,000 & & - & - \\
\hline Transportation & project & 1 & $\$$ & 68,000 & $\$$ & 68,000 & & - & - \\
\hline Other & Cost & 1 & $\$$ & $1,000,000$ & $\$$ & $1,000,000$ & & - & - \\
\hline Sub-total: & & & & & $\$$ & $7,093,000$ & $15.0 \%$ & & \\
\hline$\underline{\text { Miscellaneous }}$ & & & & & & & & & \\
\hline Training & $p-d$ & 40 & $\$$ & 800 & $\$$ & 32,000 & & - & - \\
\hline Commissioning & $p-d$ & 50 & $\$$ & 800 & $\$$ & 40,000 & & - & - \\
\hline Interest during construction & $\%$ & $3.0 \%$ & $\$$ & $43,731,400$ & $\$$ & $1,311,942$ & & - & - \\
\hline Contingencies & $\%$ & $5 \%$ & $\$$ & $43,731,400$ & $\$$ & $2,186,570$ & & - & - \\
\hline Sub-total: & & & & & $\$$ & $3,570,512$ & $7.5 \%$ & & \\
\hline Initial Costs - Total & & & & & 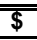 & $\overline{477,301,912}$ & $\overline{100.0 \%}$ & & \\
\hline
\end{tabular}

\begin{tabular}{|c|c|c|c|c|c|c|c|c|c|}
\hline \multirow{2}{*}{ Annual Costs (Credits) } & \multirow[t]{2}{*}{ Unit } & \multicolumn{2}{|l|}{ Quantity } & \multicolumn{2}{|l|}{ Unit Cost } & \multirow[t]{2}{*}{ Amount } & \multirow[t]{2}{*}{ Relative Costs } & \multirow[t]{2}{*}{ Quantity Range } & \multirow[t]{2}{*}{ Unit Cost Range } \\
\hline & & & & & & & & & \\
\hline Land lease & $\%$ & $2.0 \%$ & $\$$ & $3,592,209$ & $\$$ & 71,844 & & - & - \\
\hline Property taxes & $\%$ & $0.0 \%$ & $\$$ & $3,592,209$ & $\$$ & - & & - & - \\
\hline Insurance premium & $\%$ & $3.0 \%$ & $\$$ & $3,592,209$ & $\$$ & 107,766 & & - & - \\
\hline Transmission line maintenance & $\%$ & $3.0 \%$ & $\$$ & $1,500,000$ & $\$$ & 45,000 & & - & - \\
\hline Parts and labour & kWh & $102,634,537$ & $\$$ & 0.008 & $\$$ & 821,076 & & - & - \\
\hline Community benefits & - & 1 & $\$$ & 15,000 & $\$$ & 15,000 & & - & - \\
\hline Travel and accommodation & p-trip & 12 & $\$$ & 3,000 & $\$$ & 36,000 & & - & - \\
\hline General and administrative & $\%$ & $6 \%$ & $\$$ & $1,096,687$ & $\$$ & 65,801 & & - & - \\
\hline Other & Cost & 0 & $\$$ & - & $\$$ & - & & - & - \\
\hline Contingencies & $\%$ & $10 \%$ & $\$$ & $1,096,687$ & $\$$ & 109,669 & & - & - \\
\hline Annual Costs - Total & & & & & $\$$ & 1,272,157 & $100.0 \%$ & & \\
\hline Periodic Costs (Credits) & & Period & & Unit Cost & & Amount & & Interval Range & Unit Cost Range \\
\hline Drive train & Cost & $10 \mathrm{yr}$ & $\$$ & $1,000,000$ & $\$$ & $1,000,000$ & & - & - \\
\hline Blades & Cost & $15 \mathrm{yr}$ & $\$$ & $1,000,000$ & $\$$ & $1,000,000$ & & - & - \\
\hline & & & & & $\$$ & - & & - & - \\
\hline End of project life & Credit & - & $\$$ & - & $\$$ & - & & $\underline{G o}$ & o GHG Analysis sheet \\
\hline
\end{tabular}




\begin{tabular}{|c|c|c|c|c|c|}
\hline Project name & & 0.14 Shear & \multirow{6}{*}{ GHG analysis sheet used? } & \multirow{6}{*}{ yes/no } & \multirow{6}{*}{ No } \\
\hline Project location & & Duck Valley & & & \\
\hline Renewable energy delivered & $\mathrm{MWh}$ & 102,635 & & & \\
\hline Excess $R E$ available & $\mathrm{MWh}$ & 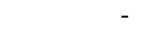 & & & \\
\hline Firm RE capacity & $\mathrm{kW}$ & & & & \\
\hline Grid type & & Central-grid & & & \\
\hline
\end{tabular}

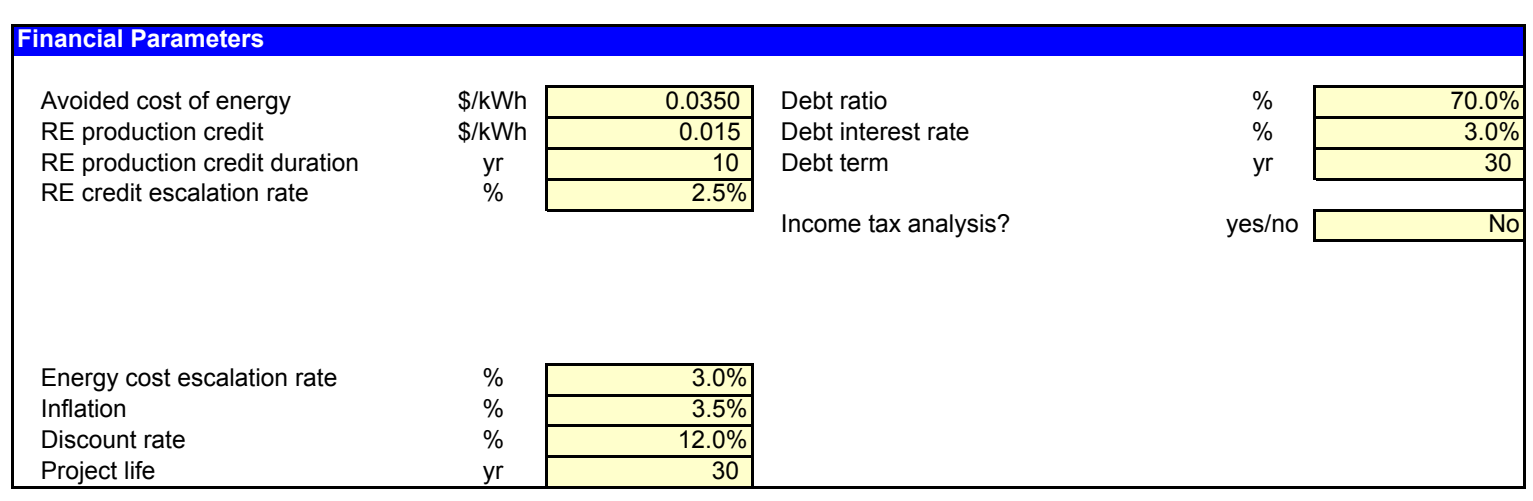

\section{Project Costs and Savings}

\begin{tabular}{|c|c|c|c|c|c|c|}
\hline \multicolumn{4}{|l|}{ Initial Costs } & \multicolumn{3}{|l|}{ Annual Costs and Debt } \\
\hline Feasibility study & $0.4 \%$ & $\$$ & 198,400 & O\&M & $\$$ & $1,272,157$ \\
\hline Development & $1.0 \%$ & $\$$ & 449,500 & & & \\
\hline Engineering & $0.9 \%$ & $\$$ & 446,500 & Debt payments - 30 yrs & $\$$ & $1,689,316$ \\
\hline $\mathrm{RE}$ equipment & $75.1 \%$ & $\$$ & $35,544,000$ & Annual Costs - Total & $\$$ & $2,961,473$ \\
\hline Balance of plant & $15.0 \%$ & $\$$ & $7,093,000$ & & & \\
\hline Miscellaneous & $7.5 \%$ & $\$$ & $3,570,512$ & Annual Savings or Income & & \\
\hline Initial Costs - Total & $100.0 \%$ & $\$$ & $47,301,912$ & $\begin{array}{l}\text { Energy savings/income } \\
\text { Capacity savings/income }\end{array}$ & $\begin{array}{l}\$ \\
\$\end{array}$ & $3,592,209$ \\
\hline Incentives/Grants & & $\$$ & - & RE production credit income - $10 \mathrm{yrs}$ & $\$$ & $1,539,518$ \\
\hline Drive train & & $\$$ & 1.000 .000 & \multicolumn{2}{|c|}{ Periodic Costs (Credits) } & \\
\hline \multirow{2}{*}{ Blades } & & $\$$ & $1,000,000$ & Schedule yr \# 15,30 & & \\
\hline & & $\$$ & - & & & \\
\hline End of project life - Credit & & $\$$ & - & & & \\
\hline
\end{tabular}

\begin{tabular}{|c|c|c|c|c|c|}
\hline \multicolumn{6}{|l|}{ Financial Feasibility } \\
\hline & & & Calculate RE production cost? & yes/no & No \\
\hline Pre-tax IRR and ROI & $\%$ & $16.6 \%$ & & & \\
\hline After-tax IRR and ROI & $\%$ & $16.6 \%$ & & & \\
\hline Simple Payback & $\mathrm{yr}$ & 12.3 & Project equity & $\$$ & $14,190,574$ \\
\hline Year-to-positive cash flow & $\mathrm{yr}$ & 5.6 & Project debt & $\$$ & $33,111,338$ \\
\hline Net Present Value - NPV & $\$$ & $4,553,257$ & Debt payments & $\$ / y r$ & $1,689,316$ \\
\hline Annual Life Cycle Savings & $\$$ & 565,258 & Debt service coverage & - & 2.34 \\
\hline Profitability Index - PI & - & 0.32 & & & \\
\hline
\end{tabular}

Version 2000 - Release 2

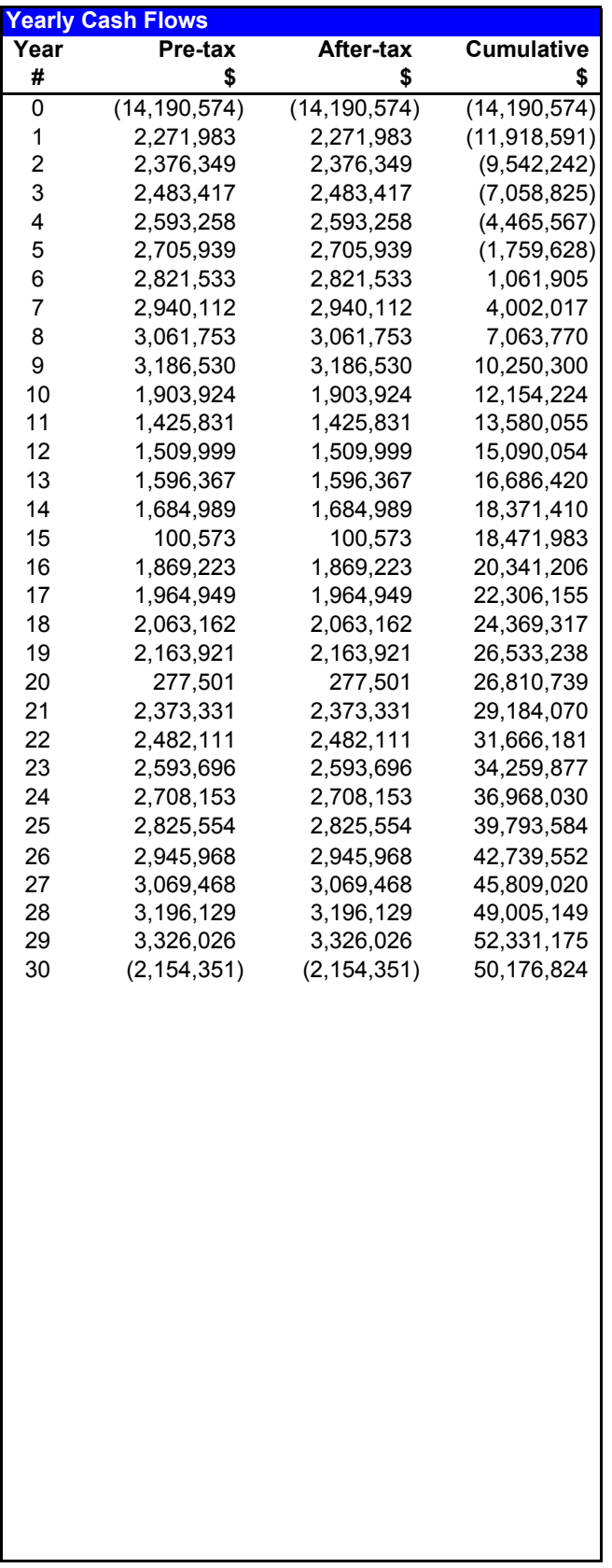

๑ Minister of Natural Resources Canada 1997 - 2000.

NRCan/CEDRL 


\section{RETScreen ${ }^{\circledR}$ Energy Model - Wind Energy Project}

\section{Site Conditions}

Project name

Project location

Nearest location for weather data

Annual average wind speed

Height of wind measurement

Wind shear exponent

Wind speed at $10 \mathrm{~m}$

Average atmospheric pressure

Annual average temperature
Estimate

\begin{tabular}{c|c|}
\multirow{4}{*}{} & O.2 Shear \\
\cline { 2 - 2 } & Duck Valley \\
\cline { 2 - 2 } & Miller Creek \\
\cline { 2 - 2 } $\mathrm{m} / \mathrm{s}$ & 6.2 \\
\cline { 2 - 2 } $\mathrm{m}$ & 20.0 \\
\cline { 2 - 2 }- & 0.20 \\
\hline $\mathrm{m} / \mathrm{s}$ & 5.4 \\
$\mathrm{kPa}$ & 91.6 \\
\cline { 2 - 2 }${ }^{\circ} \mathrm{C}$ & 11 \\
\cline { 2 - 2 } &
\end{tabular}

See Weather Database

3.0 to 100.0

0.10 to 0.25

60.0 to 103.0 -20 to 30
System Characteristics

Grid type

Wind turbine rated power

Number of turbines

Wind plant capacity

Hub height

Wind speed at hub height

Array losses

Airfoil soiling and/or icing losses

Other downtime losses

Miscellaneous losses
Estimate

- Central-grid

kW

-

$\mathrm{kW}$

$\mathrm{m}$

$\mathrm{m} / \mathrm{s}$

$\%$

$\%$

$\%$

$\%$

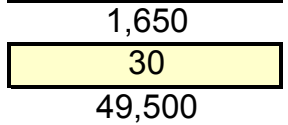

67.0

7.9

\begin{tabular}{|l|}
\hline 7.9 \\
\hline $3 \%$ \\
\hline $2 \%$ \\
\hline $2 \%$ \\
\hline $3 \%$ \\
\hline
\end{tabular}

6.0 to 100.0

3.0 to 15.0

$0 \%$ to $20 \%$

$1 \%$ to $10 \%$

$2 \%$ to $7 \%$

$2 \%$ to $6 \%$

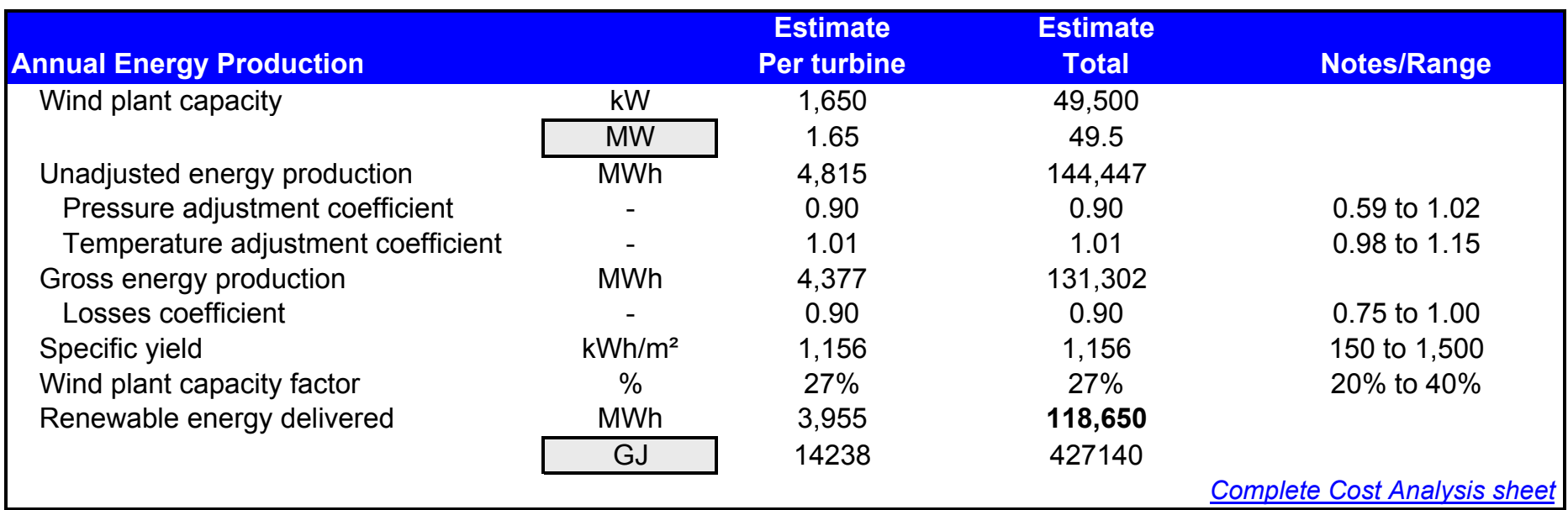


Wind Turbine Characteristics

Wind turbine rated power

Hub height

Rotor diameter

Swept area

Wind turbine manufacturer

Wind turbine model

Energy curve data source

Shape factor
Estimate

\begin{tabular}{c|c|}
\multirow{3}{*}{$\mathrm{kW}$} & 1,650 \\
\cline { 2 - 2 } $\mathrm{m}$ & 67.0 \\
\cline { 2 - 2 } $\mathrm{m}^{2}$ & 66 \\
\cline { 2 - 2 } & 3,421 \\
\cline { 2 - 2 } & Vestas Wind Systems \\
\cline { 2 - 2 } & VESTAS V66-1.65MW \\
\cline { 2 - 2 }- & Custom \\
\cline { 2 - 2 }- & 2.1 \\
\hline
\end{tabular}

Notes/Range

See Product Database

6.0 to 100.0

7 to 72

35 to 4,075

Weibull wind distribution 1.0 to 3.0

\section{Wind Turbine Production Data}

Wind speed $\quad$ Power curve data

$(\mathrm{m} / \mathrm{s})$

\begin{tabular}{|c|c|c|}
\hline$(\mathrm{m} / \mathrm{s})$ & $(\mathrm{kW})$ & (MWh/yr) \\
\hline 0 & 0.0 & - \\
\hline 1 & 0.0 & - \\
\hline 2 & 0.0 & - \\
\hline 3 & 0.0 & 214.7 \\
\hline 4 & 13.5 & 716.6 \\
\hline 5 & 80.8 & $1,533.1$ \\
\hline 6 & 169.0 & $2,588.2$ \\
\hline 7 & 289.0 & $3,761.0$ \\
\hline 8 & 448.0 & $4,937.4$ \\
\hline 9 & 644.0 & $6,033.7$ \\
\hline 10 & 858.0 & $6,992.3$ \\
\hline 11 & $1,069.0$ & $7,775.8$ \\
\hline 12 & $1,263.0$ & $8,366.1$ \\
\hline 13 & $1,431.0$ & $8,764.1$ \\
\hline 14 & $1,552.0$ & $8,985.6$ \\
\hline 15 & $1,617.0$ & $9,055.3$ \\
\hline 16 & $1,642.0$ & - \\
\hline 17 & $1,649.0$ & - \\
\hline 18 & $1,650.0$ & - \\
\hline 19 & $1,650.0$ & - \\
\hline 20 & $1,650.0$ & - \\
\hline 21 & $1,650.0$ & - \\
\hline 22 & $1,650.0$ & - \\
\hline 23 & $1,650.0$ & - \\
\hline 24 & $1,650.0$ & - \\
\hline 25 & $1,650.0$ & - \\
\hline
\end{tabular}

Power and Energy Curves

$\multimap$ Power $\rightarrow-$ Energy

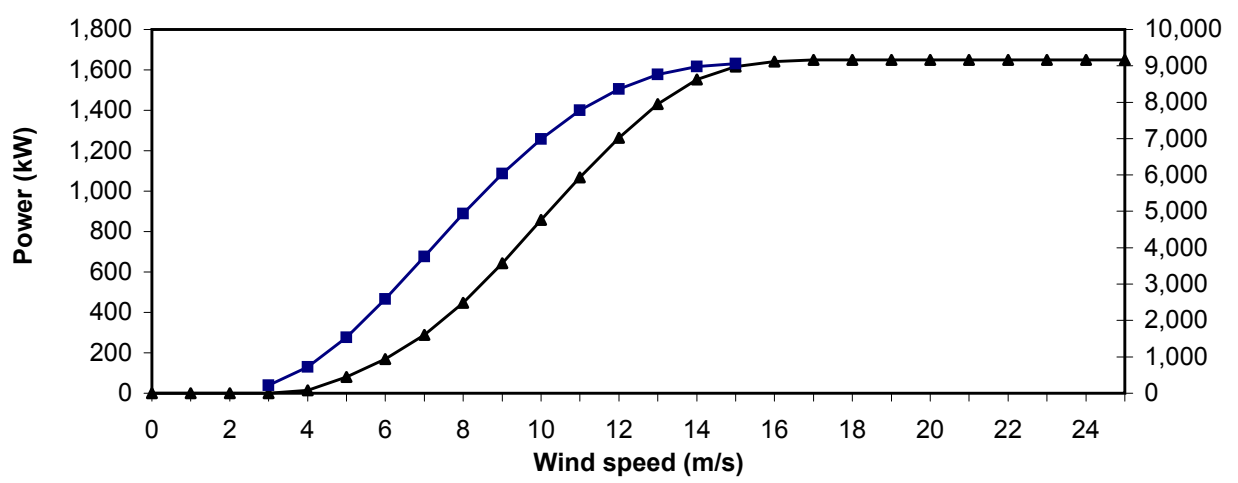

Return to

Energy Model sheet 


$$
\text { Type of project: Custom }
$$

Currency:

$\$$

Cost references:

\begin{tabular}{|c|c|c|c|c|c|c|c|c|c|}
\hline Initial Costs (Credits) & Unit & Quantity & & Unit Cost & & Amount & Relative Costs & Quantity Range & Unit Cost Range \\
\hline Feasibility Study & & & & & & & & & \\
\hline Site investigation & $p-d$ & 6 & $\$$ & 800 & $\$$ & 4,800 & & - & - \\
\hline Wind resource assessment & met tower & 2 & $\$$ & 40,000 & $\$$ & 80,000 & & - & - \\
\hline Environmental assessment & $p-d$ & 24 & $\$$ & 800 & $\$$ & 19,200 & & - & - \\
\hline Preliminary design & $p-d$ & 48 & $\$$ & 800 & $\$$ & 38,400 & & - & - \\
\hline Detailed cost estimate & $p-d$ & 18 & $\$$ & 800 & $\$$ & 14,400 & & - & - \\
\hline Report preparation & p-d & 16 & $\$$ & 800 & $\$$ & 12,800 & & - & - \\
\hline Project management & $p-d$ & 16 & $\$$ & 800 & $\$$ & 12,800 & & - & - \\
\hline Travel and accommodation & p-trip & 8 & $\$$ & 2,000 & $\$$ & 16,000 & & - & - \\
\hline Other & Cost & 0 & $\$$ & - & $\$$ & - & & - & - \\
\hline Sub-total: & & & & & $\$$ & 198,400 & $0.4 \%$ & & \\
\hline Development & & & & & & & & & \\
\hline PPA negotiation & $p-d$ & 20 & $\$$ & 1,200 & $\$$ & 24,000 & & - & - \\
\hline Permits and approvals & $\mathrm{p}-\mathrm{d}$ & 100 & $\$$ & 800 & $\$$ & 80,000 & & - & - \\
\hline Land rights & project & 0 & $\$$ & 30,000 & $\$$ & - & & - & - \\
\hline Land survey & $p-d$ & 20 & $\$$ & 600 & $\$$ & 12,000 & & - & - \\
\hline Project financing & $p-d$ & 50 & $\$$ & 1,500 & $\$$ & 75,000 & & - & - \\
\hline Legal and accounting & $p-d$ & 50 & $\$$ & 1,200 & $\$$ & 60,000 & & - & - \\
\hline Project management & $\mathrm{p}-\mathrm{yr}$ & 1.25 & $\$$ & 130,000 & $\$$ & 162,500 & & - & - \\
\hline Travel and accommodation & p-trip & 18 & $\$$ & 2,000 & $\$$ & 36,000 & & - & - \\
\hline Other & Cost & 0 & $\$$ & - & $\$$ & - & & - & - \\
\hline Sub-total: & & & & & $\$$ & 4449,500 & $101.0 \%$ & & \\
\hline Engineering & & & & & & & & & \\
\hline Wind turbine(s) micro-siting & $p-d$ & 100 & $\$$ & 800 & $\$$ & 80,000 & & - & - \\
\hline Mechanical design & $p-d$ & 50 & $\$$ & 800 & $\$$ & 40,000 & & - & - \\
\hline Electrical design & $p-d$ & 100 & $\$$ & 800 & $\$$ & 80,000 & & - & - \\
\hline Civil design & $\mathrm{p}-\mathrm{d}$ & 90 & $\$$ & 800 & $\$$ & 72,000 & & - & - \\
\hline Tenders and contracting & $\mathrm{p}-\mathrm{d}$ & 80 & $\$$ & 800 & $\$$ & 64,000 & & - & - \\
\hline Construction supervision & $\mathrm{p}-\mathrm{yr}$ & 0.85 & $\$$ & 130,000 & $\$$ & 110,500 & & - & - \\
\hline Other & Cost & 0 & $\$$ & - & $\$$ & - & & - & - \\
\hline Sub-total: & & & & & $\$$ & $\overline{446,500}$ & $0.9 \%$ & & \\
\hline Renewable Energy (RE) Equipment & & & & & & & & & \\
\hline Wind turbine(s) & $\mathrm{kW}$ & 49,500 & $\$$ & 600 & $\$$ & $29,700,000$ & & - & - \\
\hline Spare parts & $\%$ & $2.0 \%$ & $\$$ & $29,700,000$ & $\$$ & 594,000 & & - & - \\
\hline Transportation & turbine & 30 & $\$$ & 10,000 & $\$$ & 300,000 & & - & - \\
\hline Other & Cost & 49,500 & $\$$ & 100 & $\$$ & $4,950,000$ & & - & - \\
\hline Sub-total: & & & & & $\$$ & $35,544,000$ & $\overline{75.1 \%}$ & & \\
\hline Balance of Plant & & & & & & & & & \\
\hline Wind turbine(s) foundation(s) & turbine & 30 & $\$$ & 78,000 & $\$$ & $2,340,000$ & & - & - \\
\hline Wind turbine(s) erection & turbine & 30 & $\$$ & 52,000 & $\$$ & $1,560,000$ & & - & - \\
\hline Road construction & $\mathrm{km}$ & 10.00 & $\$$ & 50,000 & $\$$ & 500,000 & & - & - \\
\hline Transmission line and substation & project & 1 & $\$$ & $1,500,000$ & $\$$ & $1,500,000$ & & - & - \\
\hline Control and O\&M building(s) & building & 1 & $\$$ & 125,000 & $\$$ & 125,000 & & - & - \\
\hline Transportation & project & 1 & $\$$ & 68,000 & $\$$ & 68,000 & & - & - \\
\hline Other & Cost & 1 & $\$$ & $1,000,000$ & $\$$ & $1,000,000$ & & - & - \\
\hline Sub-total: & & & & & $\$$ & $7,093,000$ & $15.0 \%$ & & \\
\hline$\underline{\text { Miscellaneous }}$ & & & & & & & & & \\
\hline Training & $p-d$ & 40 & $\$$ & 800 & $\$$ & 32,000 & & - & - \\
\hline Commissioning & $p-d$ & 50 & $\$$ & 800 & $\$$ & 40,000 & & - & - \\
\hline Interest during construction & $\%$ & $3.0 \%$ & $\$$ & $43,731,400$ & $\$$ & $1,311,942$ & & - & - \\
\hline Contingencies & $\%$ & $5 \%$ & $\$$ & $43,731,400$ & $\$$ & $2,186,570$ & & - & - \\
\hline Sub-total: & & & & & $\$$ & $3,570,512$ & $7.5 \%$ & & \\
\hline Initial Costs - Total & & & & & 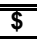 & $\overline{477,301,912}$ & $\overline{100.0 \%}$ & & \\
\hline
\end{tabular}

\begin{tabular}{|c|c|c|c|c|c|c|c|c|c|}
\hline \multirow{2}{*}{ Annual Costs (Credits) } & \multirow[t]{2}{*}{ Unit } & \multicolumn{2}{|l|}{ Quantity } & \multicolumn{2}{|l|}{ Unit Cost } & \multirow[t]{2}{*}{ Amount } & \multirow[t]{2}{*}{ Relative Costs } & \multirow[t]{2}{*}{ Quantity Range } & \multirow[t]{2}{*}{ Unit Cost Range } \\
\hline & & & & & & & & & \\
\hline Land lease & $\%$ & $2.0 \%$ & $\$$ & $4,152,750$ & $\$$ & 83,055 & & - & - \\
\hline Property taxes & $\%$ & $0.0 \%$ & $\$$ & $4,152,750$ & $\$$ & - & & - & - \\
\hline Insurance premium & $\%$ & $3.0 \%$ & $\$$ & $4,152,750$ & $\$$ & 124,583 & & - & - \\
\hline Transmission line maintenance & $\%$ & $3.0 \%$ & $\$$ & $1,500,000$ & $\$$ & 45,000 & & - & - \\
\hline Parts and labour & kWh & $118,650,011$ & $\$$ & 0.008 & $\$$ & 949,200 & & - & - \\
\hline Community benefits & - & 1 & $\$$ & 15,000 & $\$$ & 15,000 & & - & - \\
\hline Travel and accommodation & p-trip & 12 & $\$$ & 3,000 & $\$$ & 36,000 & & - & - \\
\hline General and administrative & $\%$ & $6 \%$ & $\$$ & $1,252,838$ & $\$$ & 75,170 & & - & - \\
\hline Other & Cost & 0 & $\$$ & - & $\$$ & - & & - & - \\
\hline Contingencies & $\%$ & $10 \%$ & $\$$ & $1,252,838$ & $\$$ & 125,284 & & - & - \\
\hline Annual Costs - Total & & & & & $\$$ & 1,453,292 & $100.0 \%$ & & \\
\hline Periodic Costs (Credits) & & Period & & Unit Cost & & Amount & & Interval Range & Unit Cost Range \\
\hline Drive train & Cost & $10 \mathrm{yr}$ & $\$$ & $1,000,000$ & $\$$ & $1,000,000$ & & - & - \\
\hline Blades & Cost & $15 \mathrm{yr}$ & $\$$ & $1,000,000$ & $\$$ & $1,000,000$ & & - & - \\
\hline & & & & & $\$$ & - & & - & - \\
\hline End of project life & Credit & - & $\$$ & - & $\$$ & - & & $\underline{G o}$ & o GHG Analysis sheet \\
\hline
\end{tabular}




\begin{tabular}{|c|c|c|c|c|c|}
\hline $\begin{array}{l}\text { Project name } \\
\text { Project location } \\
\text { Renewable energy delivered } \\
\text { Excess RE available } \\
\text { Firm RE capacity } \\
\text { Grid type }\end{array}$ & $\begin{array}{c}\text { MWh } \\
\text { MWh } \\
\text { kW }\end{array}$ & $\begin{array}{r}0.2 \text { Shear } \\
\text { Duck Valley } \\
118,650 \\
- \\
- \\
\text { Central-grid }\end{array}$ & GHG analysis sheet used? & yes/no & No \\
\hline \multicolumn{6}{|l|}{ Financial Parameters } \\
\hline $\begin{array}{l}\text { Avoided cost of energy } \\
\text { RE production credit } \\
\text { RE production credit duration } \\
\text { RE credit escalation rate }\end{array}$ & $\begin{array}{c}\$ / \mathrm{kWh} \\
\$ / \mathrm{kWh} \\
\mathrm{yr} \\
\%\end{array}$ & \begin{tabular}{r|}
0.0350 \\
0.015 \\
10 \\
$2.5 \%$ \\
\end{tabular} & $\begin{array}{l}\text { Debt ratio } \\
\text { Debt interest rate } \\
\text { Debt term }\end{array}$ & $\begin{array}{l}\% \\
\% \\
\mathrm{yr}\end{array}$ & \begin{tabular}{|c|}
$70.0 \%$ \\
$3.0 \%$ \\
30 \\
\end{tabular} \\
\hline $\begin{array}{l}\text { Energy cost escalation rate } \\
\text { Inflation } \\
\text { Discount rate } \\
\text { Project life }\end{array}$ & $\begin{array}{l}\% \\
\% \\
\% \\
\mathrm{yr}\end{array}$ & \begin{tabular}{|r|}
$3.0 \%$ \\
$3.5 \%$ \\
$12.0 \%$ \\
30
\end{tabular} & & & \\
\hline
\end{tabular}

\section{Project Costs and Savings}

\begin{tabular}{|c|c|c|c|c|c|c|}
\hline \multicolumn{4}{|l|}{ Initial Costs } & \multicolumn{3}{|l|}{ Annual Costs and Debt } \\
\hline Feasibility study & $0.4 \%$ & $\$$ & 198,400 & O\&M & $\$$ & $1,453,292$ \\
\hline Development & $1.0 \%$ & $\$$ & 449,500 & & & \\
\hline Engineering & $0.9 \%$ & $\$$ & 446,500 & Debt payments - 30 yrs & $\$$ & $1,689,316$ \\
\hline RE equipment & $75.1 \%$ & $\$$ & $35,544,000$ & Annual Costs - Total & $\$$ & $3,142,608$ \\
\hline Balance of plant & $15.0 \%$ & $\$$ & $7,093,000$ & & & \\
\hline Miscellaneous & $7.5 \%$ & $\$$ & $3,570,512$ & Annual Savings or Income & & \\
\hline Initial Costs - Total & $100.0 \%$ & $\$$ & $47,301,912$ & Energy savings/income & $\$$ & $4,152,750$ \\
\hline \multirow[t]{2}{*}{ Incentives/Grants } & & $\$$ & - & $\begin{array}{l}\text { Capacity savings/income } \\
\text { RE production credit income - } 10 \text { yrs }\end{array}$ & $\begin{array}{l}\$ \\
\$\end{array}$ & $1,779,750$ \\
\hline & & & & Annual Savings - Total & $\$$ & $5,932,501$ \\
\hline \multicolumn{7}{|l|}{ Periodic Costs (Credits) } \\
\hline Drive train & & $\$$ & $1,000,000$ & Schedule yr \# 10,20,30 & & \\
\hline \multirow[t]{2}{*}{ Blades } & & $\$$ & $1,000,000$ & Schedule yr \# 15,30 & & \\
\hline & & $\$$ & - & & & \\
\hline End of project life - Credit & & $\$$ & - & & & \\
\hline
\end{tabular}

\section{Financial Feasibility}

Pre-tax IRR and ROI After-tax IRR and ROI

Simple Payback

Year-to-positive cash flow

Year-to-positive cash flow
Net Present Value - NPV

Annual Life Cycle Savings

Profitability Index - PI

Version 2000 - Release

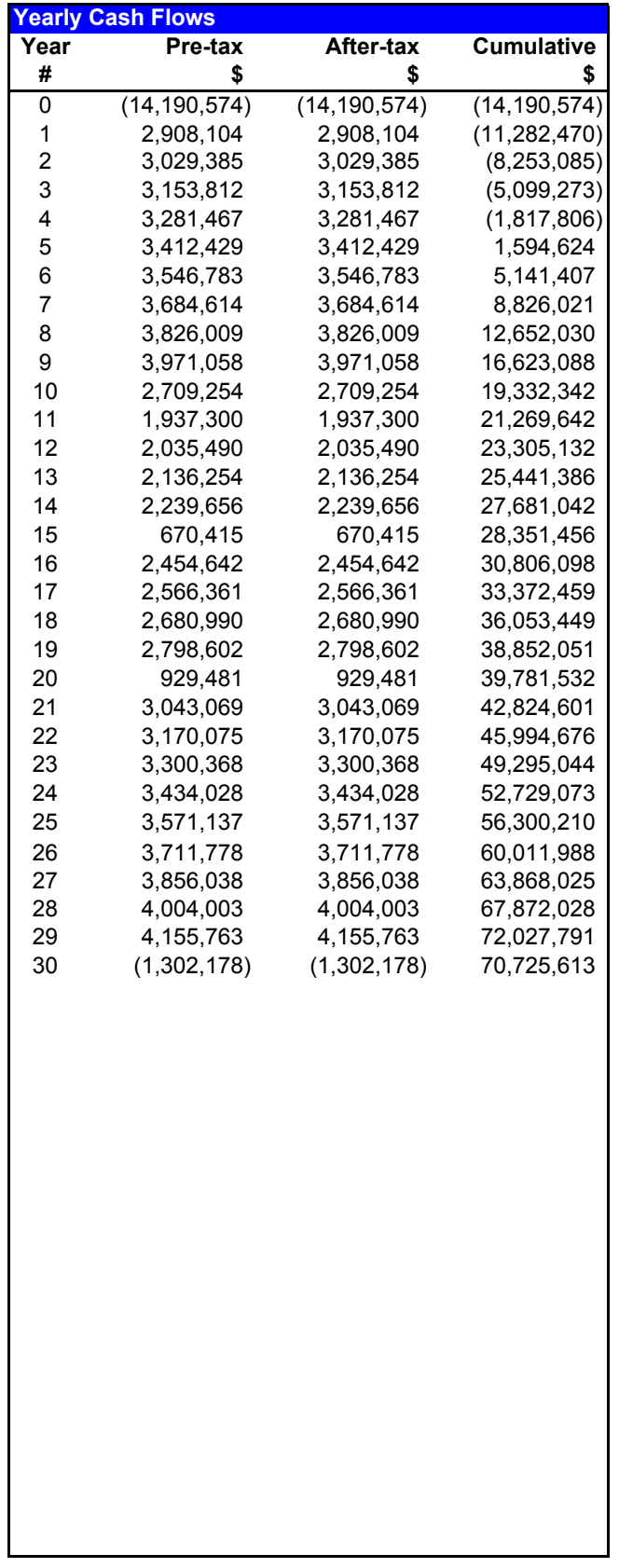

NRCan/CEDRL 


\section{RETScreen ${ }^{\circledR}$ Energy Model - Wind Energy Project}

\section{Site Conditions}

Project name

Project location

Nearest location for weather data

Annual average wind speed

Height of wind measurement

Wind shear exponent

Wind speed at $10 \mathrm{~m}$

Average atmospheric pressure

Annual average temperature
Estimate

Notes/Range

\begin{tabular}{c|c|}
\multirow{4}{*}{} & 0.26 Shear \\
\cline { 2 - 2 } & Duck Valley \\
\cline { 2 - 2 } $\mathrm{m} / \mathrm{s}$ & Miller Creek \\
\cline { 2 - 2 } $\mathrm{m}$ & 6.2 \\
\cline { 2 - 2 }- & 20.0 \\
\cline { 2 - 2 } $\mathrm{m} / \mathrm{s}$ & 0.26 \\
$\mathrm{kPa}$ & 5.2 \\
& 91.6 \\
\hline & 11
\end{tabular}

See Weather Database

3.0 to 100.0

0.10 to 0.25

60.0 to 103.0 -20 to 30

\section{System Characteristics}

Grid type

Wind turbine rated power

Number of turbines

Wind plant capacity

Hub height

Wind speed at hub height

Array losses

Airfoil soiling and/or icing losses

Other downtime losses

Miscellaneous losses

\begin{tabular}{c|c}
\multicolumn{1}{c}{} & \multicolumn{1}{c}{ Estimate } \\
\hline kW & Central-grid \\
\cline { 2 - 2 }- & 1,650 \\
\cline { 2 - 2 } kW & 30 \\
m & 49,500 \\
m/s & 67.0 \\
$\%$ & 8.5 \\
$\%$ & $3 \%$ \\
$\%$ & $2 \%$ \\
\cline { 2 - 2 }$\%$ & $2 \%$ \\
\cline { 2 - 2 } & $3 \%$ \\
\hline
\end{tabular}

Notes/Range

Complete Equipment Data sheet

6.0 to 100.0

3.0 to 15.0

$0 \%$ to $20 \%$

$1 \%$ to $10 \%$

$2 \%$ to $7 \%$

$2 \%$ to $6 \%$

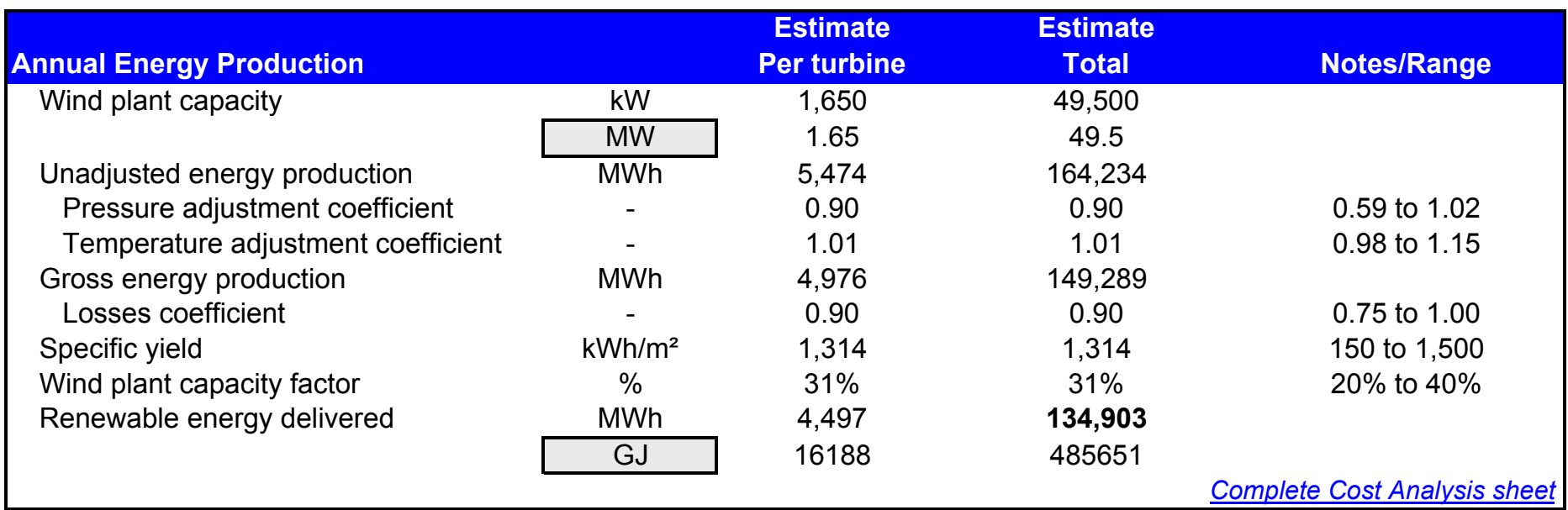


Wind Turbine Characteristics

Wind turbine rated power

Hub height

Rotor diameter

Swept area

Wind turbine manufacturer

Wind turbine model

Energy curve data source

Shape factor
Estimate

\begin{tabular}{c|c|}
\multirow{3}{*}{$\mathrm{kW}$} & 1,650 \\
\cline { 2 - 2 } $\mathrm{m}$ & 67.0 \\
\cline { 2 - 2 } $\mathrm{m}^{2}$ & 66 \\
\cline { 2 - 2 } & 3,421 \\
\cline { 2 - 2 } & Vestas Wind Systems \\
\cline { 2 - 2 } & VESTAS V66-1.65MW \\
\cline { 2 - 2 }- & Custom \\
\cline { 2 - 2 }- & 2.1 \\
\hline
\end{tabular}

Notes/Range

See Product Database

6.0 to 100.0

7 to 72

35 to 4,075

Weibull wind distribution 1.0 to 3.0

\section{Wind Turbine Production Data}

Wind speed $\quad$ Power curve data

$(\mathrm{m} / \mathrm{s})$

\begin{tabular}{|c|c|c|}
\hline$(\mathrm{m} / \mathrm{s})$ & $(\mathrm{kW})$ & (MWh/yr) \\
\hline 0 & 0.0 & - \\
\hline 1 & 0.0 & - \\
\hline 2 & 0.0 & - \\
\hline 3 & 0.0 & 214.7 \\
\hline 4 & 13.5 & 716.6 \\
\hline 5 & 80.8 & $1,533.1$ \\
\hline 6 & 169.0 & $2,588.2$ \\
\hline 7 & 289.0 & $3,761.0$ \\
\hline 8 & 448.0 & $4,937.4$ \\
\hline 9 & 644.0 & $6,033.7$ \\
\hline 10 & 858.0 & $6,992.3$ \\
\hline 11 & $1,069.0$ & $7,775.8$ \\
\hline 12 & $1,263.0$ & $8,366.1$ \\
\hline 13 & $1,431.0$ & $8,764.1$ \\
\hline 14 & $1,552.0$ & $8,985.6$ \\
\hline 15 & $1,617.0$ & $9,055.3$ \\
\hline 16 & $1,642.0$ & - \\
\hline 17 & $1,649.0$ & - \\
\hline 18 & $1,650.0$ & - \\
\hline 19 & $1,650.0$ & - \\
\hline 20 & $1,650.0$ & - \\
\hline 21 & $1,650.0$ & - \\
\hline 22 & $1,650.0$ & - \\
\hline 23 & $1,650.0$ & - \\
\hline 24 & $1,650.0$ & - \\
\hline 25 & $1,650.0$ & - \\
\hline
\end{tabular}

Power and Energy Curves

$\longrightarrow$ Power $\longrightarrow$ Energy

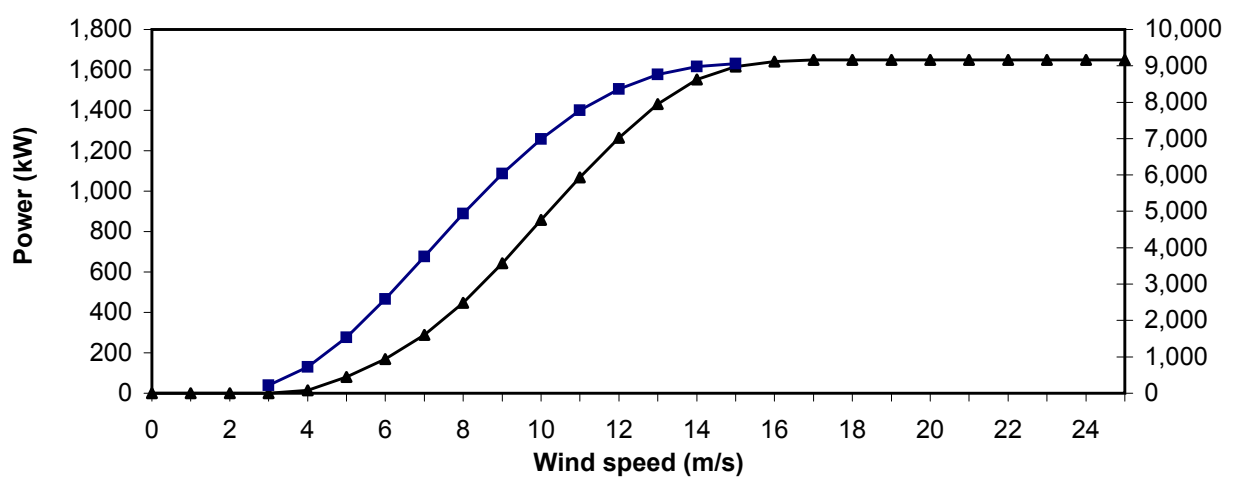

Return to

Energy Model sheet 


$$
\text { Type of project: Custom }
$$

Currency:

$\$$

Cost references:

\begin{tabular}{|c|c|c|c|c|c|c|c|c|c|}
\hline Initial Costs (Credits) & Unit & Quantity & & Unit Cost & & Amount & Relative Costs & Quantity Range & Unit Cost Range \\
\hline Feasibility Study & & & & & & & & & \\
\hline Site investigation & $p-d$ & 6 & $\$$ & 800 & $\$$ & 4,800 & & - & - \\
\hline Wind resource assessment & met tower & 2 & $\$$ & 40,000 & $\$$ & 80,000 & & - & - \\
\hline Environmental assessment & $p-d$ & 24 & $\$$ & 800 & $\$$ & 19,200 & & - & - \\
\hline Preliminary design & $p-d$ & 48 & $\$$ & 800 & $\$$ & 38,400 & & - & - \\
\hline Detailed cost estimate & $p-d$ & 18 & $\$$ & 800 & $\$$ & 14,400 & & - & - \\
\hline Report preparation & p-d & 16 & $\$$ & 800 & $\$$ & 12,800 & & - & - \\
\hline Project management & $p-d$ & 16 & $\$$ & 800 & $\$$ & 12,800 & & - & - \\
\hline Travel and accommodation & p-trip & 8 & $\$$ & 2,000 & $\$$ & 16,000 & & - & - \\
\hline Other & Cost & 0 & $\$$ & - & $\$$ & - & & - & - \\
\hline Sub-total: & & & & & $\$$ & 198,400 & $0.4 \%$ & & \\
\hline Development & & & & & & & & & \\
\hline PPA negotiation & $p-d$ & 20 & $\$$ & 1,200 & $\$$ & 24,000 & & - & - \\
\hline Permits and approvals & $\mathrm{p}-\mathrm{d}$ & 100 & $\$$ & 800 & $\$$ & 80,000 & & - & - \\
\hline Land rights & project & 0 & $\$$ & 30,000 & $\$$ & - & & - & - \\
\hline Land survey & $p-d$ & 20 & $\$$ & 600 & $\$$ & 12,000 & & - & - \\
\hline Project financing & $p-d$ & 50 & $\$$ & 1,500 & $\$$ & 75,000 & & - & - \\
\hline Legal and accounting & $p-d$ & 50 & $\$$ & 1,200 & $\$$ & 60,000 & & - & - \\
\hline Project management & $\mathrm{p}-\mathrm{yr}$ & 1.25 & $\$$ & 130,000 & $\$$ & 162,500 & & - & - \\
\hline Travel and accommodation & p-trip & 18 & $\$$ & 2,000 & $\$$ & 36,000 & & - & - \\
\hline Other & Cost & 0 & $\$$ & - & $\$$ & - & & - & - \\
\hline Sub-total: & & & & & $\$$ & 4449,500 & $101.0 \%$ & & \\
\hline Engineering & & & & & & & & & \\
\hline Wind turbine(s) micro-siting & $p-d$ & 100 & $\$$ & 800 & $\$$ & 80,000 & & - & - \\
\hline Mechanical design & $p-d$ & 50 & $\$$ & 800 & $\$$ & 40,000 & & - & - \\
\hline Electrical design & $p-d$ & 100 & $\$$ & 800 & $\$$ & 80,000 & & - & - \\
\hline Civil design & $\mathrm{p}-\mathrm{d}$ & 90 & $\$$ & 800 & $\$$ & 72,000 & & - & - \\
\hline Tenders and contracting & $\mathrm{p}-\mathrm{d}$ & 80 & $\$$ & 800 & $\$$ & 64,000 & & - & - \\
\hline Construction supervision & $\mathrm{p}-\mathrm{yr}$ & 0.85 & $\$$ & 130,000 & $\$$ & 110,500 & & - & - \\
\hline Other & Cost & 0 & $\$$ & - & $\$$ & - & & - & - \\
\hline Sub-total: & & & & & $\$$ & $\overline{446,500}$ & $0.9 \%$ & & \\
\hline Renewable Energy (RE) Equipment & & & & & & & & & \\
\hline Wind turbine(s) & $\mathrm{kW}$ & 49,500 & $\$$ & 600 & $\$$ & $29,700,000$ & & - & - \\
\hline Spare parts & $\%$ & $2.0 \%$ & $\$$ & $29,700,000$ & $\$$ & 594,000 & & - & - \\
\hline Transportation & turbine & 30 & $\$$ & 10,000 & $\$$ & 300,000 & & - & - \\
\hline Other & Cost & 49,500 & $\$$ & 100 & $\$$ & $4,950,000$ & & - & - \\
\hline Sub-total: & & & & & $\$$ & $35,544,000$ & $\overline{75.1 \%}$ & & \\
\hline Balance of Plant & & & & & & & & & \\
\hline Wind turbine(s) foundation(s) & turbine & 30 & $\$$ & 78,000 & $\$$ & $2,340,000$ & & - & - \\
\hline Wind turbine(s) erection & turbine & 30 & $\$$ & 52,000 & $\$$ & $1,560,000$ & & - & - \\
\hline Road construction & $\mathrm{km}$ & 10.00 & $\$$ & 50,000 & $\$$ & 500,000 & & - & - \\
\hline Transmission line and substation & project & 1 & $\$$ & $1,500,000$ & $\$$ & $1,500,000$ & & - & - \\
\hline Control and O\&M building(s) & building & 1 & $\$$ & 125,000 & $\$$ & 125,000 & & - & - \\
\hline Transportation & project & 1 & $\$$ & 68,000 & $\$$ & 68,000 & & - & - \\
\hline Other & Cost & 1 & $\$$ & $1,000,000$ & $\$$ & $1,000,000$ & & - & - \\
\hline Sub-total: & & & & & $\$$ & $7,093,000$ & $15.0 \%$ & & \\
\hline$\underline{\text { Miscellaneous }}$ & & & & & & & & & \\
\hline Training & $p-d$ & 40 & $\$$ & 800 & $\$$ & 32,000 & & - & - \\
\hline Commissioning & $p-d$ & 50 & $\$$ & 800 & $\$$ & 40,000 & & - & - \\
\hline Interest during construction & $\%$ & $3.0 \%$ & $\$$ & $43,731,400$ & $\$$ & $1,311,942$ & & - & - \\
\hline Contingencies & $\%$ & $5 \%$ & $\$$ & $43,731,400$ & $\$$ & $2,186,570$ & & - & - \\
\hline Sub-total: & & & & & $\$$ & $3,570,512$ & $7.5 \%$ & & \\
\hline Initial Costs - Total & & & & & 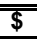 & $\overline{477,301,912}$ & $\overline{100.0 \%}$ & & \\
\hline
\end{tabular}

\begin{tabular}{|c|c|c|c|c|c|c|c|c|c|}
\hline \multirow{2}{*}{ Annual Costs (Credits) } & \multirow[t]{2}{*}{ Unit } & \multicolumn{2}{|l|}{ Quantity } & \multicolumn{2}{|l|}{ Unit Cost } & \multirow[t]{2}{*}{ Amount } & \multirow[t]{2}{*}{ Relative Costs } & \multirow[t]{2}{*}{ Quantity Range } & \multirow[t]{2}{*}{ Unit Cost Range } \\
\hline & & & & & & & & & \\
\hline Land lease & $\%$ & $2.0 \%$ & $\$$ & $4,721,612$ & $\$$ & 94,432 & & - & - \\
\hline Property taxes & $\%$ & $0.0 \%$ & $\$$ & $4,721,612$ & $\$$ & - & & - & - \\
\hline Insurance premium & $\%$ & $3.0 \%$ & $\$$ & $4,721,612$ & $\$$ & 141,648 & & - & - \\
\hline Transmission line maintenance & $\%$ & $3.0 \%$ & $\$$ & $1,500,000$ & $\$$ & 45,000 & & - & - \\
\hline Parts and labour & kWh & $134,903,192$ & $\$$ & 0.008 & $\$$ & $1,079,226$ & & - & - \\
\hline Community benefits & - & 1 & $\$$ & 15,000 & $\$$ & 15,000 & & - & - \\
\hline Travel and accommodation & p-trip & 12 & $\$$ & 3,000 & $\$$ & 36,000 & & - & - \\
\hline General and administrative & $\%$ & $6 \%$ & $\$$ & $1,411,306$ & $\$$ & 84,678 & & - & - \\
\hline Other & Cost & 0 & $\$$ & - & $\$$ & - & & - & - \\
\hline Contingencies & $\%$ & $10 \%$ & $\$$ & $1,411,306$ & $\$$ & 141,131 & & - & - \\
\hline Annual Costs - Total & & & & & $\$$ & $1,637,115$ & $100.0 \%$ & & \\
\hline Periodic Costs (Credits) & & Period & & Unit Cost & & Amount & & Interval Range & Unit Cost Range \\
\hline Drive train & Cost & $10 \mathrm{yr}$ & $\$$ & $1,000,000$ & $\$$ & $1,000,000$ & & - & - \\
\hline Blades & Cost & $15 \mathrm{yr}$ & $\$$ & $1,000,000$ & $\$$ & $1,000,000$ & & - & - \\
\hline & & & & & $\$$ & - & & - & - \\
\hline End of project life & Credit & - & $\$$ & - & $\$$ & - & & $\underline{G o}$ & o GHG Analysis sheet \\
\hline
\end{tabular}




\begin{tabular}{|c|c|c|c|c|c|}
\hline $\begin{array}{l}\text { Project name } \\
\text { Project location } \\
\text { Renewable energy delivered } \\
\text { Excess RE available } \\
\text { Firm RE capacity } \\
\text { Grid type }\end{array}$ & $\begin{array}{c}\text { MWh } \\
\text { MWh } \\
\text { kW }\end{array}$ & $\begin{array}{r}0.26 \text { Shear } \\
\text { Duck Valley } \\
134,903 \\
- \\
- \\
\text { Central-grid }\end{array}$ & GHG analysis sheet used? & yes/no & No \\
\hline \multicolumn{6}{|l|}{ Financial Parameters } \\
\hline $\begin{array}{l}\text { Avoided cost of energy } \\
\text { RE production credit } \\
\text { RE production credit duration } \\
\text { RE credit escalation rate }\end{array}$ & $\begin{array}{l}\$ / k W h \\
\$ / k W h \\
y r \\
\%\end{array}$ & \begin{tabular}{r|}
0.0350 \\
0.015 \\
10 \\
$2.5 \%$ \\
\end{tabular} & $\begin{array}{l}\text { Debt ratio } \\
\text { Debt interest rate } \\
\text { Debt term }\end{array}$ & $\begin{array}{c}\% \\
\% \\
\mathrm{yr}\end{array}$ & $\begin{array}{c}70.0 \% \\
3.0 \% \\
30 \\
\end{array}$ \\
\hline $\begin{array}{l}\text { Energy cost escalation rate } \\
\text { Inflation } \\
\text { Discount rate } \\
\text { Project life }\end{array}$ & $\begin{array}{l}\% \\
\% \\
\% \\
y r\end{array}$ & \begin{tabular}{|r|}
$3.0 \%$ \\
$3.5 \%$ \\
$12.0 \%$ \\
30
\end{tabular} & & & \\
\hline
\end{tabular}

\section{Project Costs and Savings}

\begin{tabular}{|c|c|c|c|c|c|c|}
\hline \multicolumn{4}{|l|}{ Initial Costs } & \multicolumn{3}{|l|}{ Annual Costs and Debt } \\
\hline Feasibility study & $0.4 \%$ & $\$$ & 198,400 & O\&M & $\$$ & $1,637,115$ \\
\hline Development & $1.0 \%$ & $\$$ & 449,500 & & & \\
\hline Engineering & $0.9 \%$ & $\$$ & 446,500 & Debt payments - 30 yrs & $\$$ & $1,689,316$ \\
\hline RE equipment & $75.1 \%$ & $\$$ & $35,544,000$ & Annual Costs - Total & $\$$ & $3,326,431$ \\
\hline Balance of plant & $15.0 \%$ & $\$$ & $7,093,000$ & & & \\
\hline Miscellaneous & $7.5 \%$ & $\$$ & $3,570,512$ & Annual Savings or Income & & \\
\hline Initial Costs - Total & $100.0 \%$ & $\$$ & $47,301,912$ & Energy savings/income & $\$$ & $4,721,612$ \\
\hline Incentives/Grants & & $\$$ & - & $\begin{array}{l}\text { Capacity savings/income } \\
\text { RE production credit income - } 10 \text { yrs }\end{array}$ & $\begin{array}{l}\$ \\
\$\end{array}$ & $2,023,548$ \\
\hline & & & & Annual Savings - Total & $\$$ & $6,745,160$ \\
\hline \multicolumn{7}{|l|}{ Periodic Costs (Credits) } \\
\hline Drive train & & $\$$ & $1,000,000$ & Schedule yr \# 10,20,30 & & \\
\hline \multirow[t]{2}{*}{ Blades } & & $\$$ & $1,000,000$ & Schedule yr \# 15,30 & & \\
\hline & & $\$$ & - & & & \\
\hline End of project life - Credit & & $\$$ & - & & & \\
\hline
\end{tabular}

\section{Financial Feasibility}

Pre-tax IRR and ROI After-tax IRR and ROI

Simple Payback

Year-to-positive cash flow

Year-to-positive cash flow
Net Present Value - NPV

Annual Life Cycle Savings

Profitability Index - PI

Version 2000 - Release 2

\begin{tabular}{|c|c|c|c|}
\hline $\operatorname{arly}$ & & & \\
\hline Year & Pre-tax & After-tax & Cumulative \\
\hline \# & $\$$ & $\$$ & $\$$ \\
\hline 0 & $(14,190,574)$ & $(14,190,574)$ & $(14,190,574)$ \\
\hline 1 & $3,553,667$ & $3,553,667$ & $(10,636,907)$ \\
\hline 2 & $3,692,113$ & $3,692,113$ & $(6,944,794)$ \\
\hline 3 & $3,834,158$ & $3,834,158$ & $(3,110,636)$ \\
\hline 4 & $3,979,891$ & $3,979,891$ & 869,255 \\
\hline 5 & $4,129,406$ & $4,129,406$ & $4,998,660$ \\
\hline 6 & $4,282,798$ & $4,282,798$ & $9,281,458$ \\
\hline 7 & $4,440,166$ & $4,440,166$ & $13,721,624$ \\
\hline 8 & $4,601,609$ & $4,601,609$ & $18,323,233$ \\
\hline 9 & $4,767,231$ & $4,767,231$ & $23,090,464$ \\
\hline 10 & $3,526,536$ & $3,526,536$ & $26,617,000$ \\
\hline 11 & $2,456,360$ & $2,456,360$ & $29,073,361$ \\
\hline 12 & $2,568,780$ & $2,568,780$ & $31,642,141$ \\
\hline 13 & $2,684,154$ & $2,684,154$ & $34,326,295$ \\
\hline 14 & $2,802,556$ & $2,802,556$ & $37,128,851$ \\
\hline 15 & $1,248,714$ & $1,248,714$ & $38,377,564$ \\
\hline 16 & $3,048,750$ & $3,048,750$ & $41,426,315$ \\
\hline 17 & $3,176,698$ & $3,176,698$ & $44,603,013$ \\
\hline 18 & $3,307,988$ & $3,307,988$ & $47,911,001$ \\
\hline 19 & $3,442,703$ & $3,442,703$ & $51,353,704$ \\
\hline 20 & $1,591,138$ & $1,591,138$ & $52,944,842$ \\
\hline 21 & $3,722,746$ & $3,722,746$ & $56,667,588$ \\
\hline 22 & $3,868,251$ & $3,868,251$ & $60,535,839$ \\
\hline 23 & $4,017,530$ & $4,017,530$ & $64,553,369$ \\
\hline 24 & $4,170,677$ & $4,170,677$ & $68,724,046$ \\
\hline 25 & $4,327,786$ & $4,327,786$ & $73,051,832$ \\
\hline 26 & $4,488,955$ & $4,488,955$ & $77,540,787$ \\
\hline 27 & $4,654,282$ & $4,654,282$ & $82,195,069$ \\
\hline 28 & $4,823,867$ & $4,823,867$ & $87,018,936$ \\
\hline 29 & 4,997,815 & $4,997,815$ & $92,016,751$ \\
\hline 30 & $(437,357)$ & $(437,357)$ & $91,579,394$ \\
\hline & & & \\
\hline & & & \\
\hline & & & \\
\hline & & & \\
\hline & & & \\
\hline & & & \\
\hline & & & \\
\hline & & & \\
\hline & & & \\
\hline & & & \\
\hline & & & \\
\hline & & & \\
\hline & & & \\
\hline
\end{tabular}

NRCan/CEDRL 